\title{
Výzkum ekologické gramotnosti studentů středních odborných škol
}

Jan Činčera, Petr Štěpánek

Envigogika 2007/II/1 - Recenzované články/ Reveiwed Papers

Publikováno/Published 16. 04. 2007

DOI: http://dx.doi.org/10.14712/18023061.12

\begin{abstract}
Abstrakt:
Článek prezentuje výsledky výzkumu environmentální gramotnosti mezi studenty středních odborných škol. Podle něj čeští středoškolští studenti většinou zastávají proenvironmentální postoje, ale jejich ochota k proenvironmentálnímu jednání je, zejména $v$ oblastech náročných na čas či peníze, malá.
\end{abstract}

\section{Klíčová slova:}

Environmentální gramotnost, ekogramotnost, střední odborné školy, NEP, environmentální postoje, proenvironmentální jednání

\section{Abstract:}

The article introduces a research into environmental literacy in a group of students of high vocational schools. According to it, Czech high school students agree with most pro-environmental statements but their willingness to act in a pro-environmental way, especially in more time and money consuming areas, is very low.

\section{Key words:}

Environmental literacy, ecoliteracy, high vocational school, NEP, environmental attitudes, environmental behaviour 


\section{Úvod}

V souvislosti s probíhající školní reformou je diskutována i otázka cílových kompetencí studenta v oblasti environmentální výchovy. Připravovaný Rámcový vzdělávací program (RVP) pro gymnázia definuje postoje, hodnoty vědomosti, dovednosti i schopnosti, jakými by student po ukončení studia měl disponovat (Rámcový vzdělávací program pro gymnázia, 2006). Rámcové vzdělávací programy tak vytváŕí určitou národní normu toho, co se někdy označuje jako ekologická gramotnost (též environmentální gramotnost, ekogramotnost). Jaká je situace na středních školách v době, kdy RVP nebyly dosud přijaty? Cílem článku je představit výsledky průzkumu, který se na malém vzorku studentů a studentek pokusil na tyto otázky odpovědět.

Průzkum ověřuje tři základní hypotézy:

H1: Studenti 4. ročníků SPŠS zastávají častěji proenvironmentální postoje než studenti 1. ročníků.

H2: Menšina studentů SPŠS zastává proenvironmentální postoje. jednání.

H3: Menšina studentů SPŠS preferuje ve svém životě environmentálně příznivé

Hypotéza 1 byla zformulována na základě nejednoznačných výsledků průzkumu Kulich-Dobiášová (Kulich; Dobiášová, 2003), podle kterých míra proenvironmentálních postojů $v$ některých prípadech $s$ rostoucím věkem klesá, $v$ jiných roste. Hypotéza 2 reflektuje rozpor mezi průzkumem Kulich-Dobiášová (Kulich; Dobiášová, 2003) indikujícím nízkou míru proenvironmentálních postojů žáků a průzkumy environmentálních postojů obyvatel České republiky (Franěk, 2006; Samanová, 2006a; Samanová, 2006b) odrážejících spíše proenvironmentální a neantropocentrické většinové postoje. Hypotéza 3 odráží výsledky výzkumů Centra pro výzkum veřejného mínění (Samanová, 2006a; Samanová, 2006b) a v dalších pracích reflektovaný rozpor mezi znalostmi, postoji a jednáním (Morrone; Mancl; Carr, 2001; Soukup, 2001).

\section{Nástroje na měření ekogramotnosti}

Přestože pojem „ekogramotnost" je poněkud vágní, zpravidla je definován jako vymezení určitých okruhů znalostí, hodnot, modelových postojů a dovedností. Např́klad The Middle School Environmental Literacy Instrument (MSELI) se skládá z pěti základních částí:

- Identifikační část

- Problémy, které znám - identifikace problémů, se kterými jsou respondenti obeznámeni

- Ekologické základy - test s uzavřenými otázkami

- Co si o věcech myslím a co s nimi můžu dělat - měření znalostí a dovedností relevantních k proenvironmentálnímu jednání

- Evaluace problémové analýzy a akčních dovedností - prezentovány scénáře; respondenti pojmenovávají problém, vyhodnocují a navrhují nejlepší řešení (Culen; Mony, 2003) 
Vymezení environmentální gramotnosti se ale u jednotlivých autorů velice liší. Michael Weber například navrhl nahradit standardní měření environmentálních znalostí měřením "vnímání environmentálních rizik" (perceptions of environmental risk; PER) (Weber; Hair; Fowler, 2000). Škála byla založena na subjektivním bodování různých typů rizikových situací (např. „Pojídání ústřic nebo korýšů, kteří byli chyceni ve znečištěné vodě."). Jiný systém byl vyvinut Morronem, Manclem a Carrem (2001) na měření ekogramotnosti obyvatel Ohia. Zajímavým výstupem jejich měření bylo zjištění, že vztah mezi znalostmi a starostí o životní prostředí je komplikovaný a např. studenti s vysokým stupněm znalostí o životním prostředí mohou pocit́ovat problémy stejně závažně, jako příslušníci menšin s malými znalostmi.

Nejdůležitější postavení mezi měřícími nástroji má tzv. Nové environmentální paradigma (NEP). Nástroj byl vyvinutý v roce 1978 a revidovaný v roce 1992. Škála byla vytvořena na základě protikladu mezi tehdejšími většinovými postoji, označovaným jako „dominantní společenské paradigma" (DSP) a postoji alternativními, označenými jako "nové environmentální paradigma". Nástroj je proto konstruován tak, že jeho jednotlivé dimenze (vědomí krize, vědomí omezenosti zdrojư a mezí rừstu, propojenost člověka s přírodou, neantropocentrismus a vědomí narušené rovnováhy) jsou prezentovány z hlediska "nového" i „dominantního" pohledu.

Přestože NEP prošel mnohou kritikou, zůstává stále nejdůležitějším nástrojem na měření ekogramotnosti. Cordano, Welcomer a Scherer považují za vhodnější pưvodní škálu NEP než škálu revidovanou a doporučují jí používat v kombinaci s dalším měřícím nástrojem (Cordano; Welcomer; Scherer, 2003). Oproti tomu LaLonde a Jackson upozorňují na zastaralost nástroje. V další kritice upozorňují na jeho kvantitativní charakter, nebezpečí zjednodušené interpretace naměřených výsledků (vysoké NEP skóre = vysoká míra proenvironmentálních postojů), archaický slovosled či zavádějící charakter některých otázek (např. "Rovnováha na Zemi je velmi křehká a mưže být snadno rozvrácena.") (LaLonde; Jackson, 2002). Modifikace NEP navrhuje i La Trobe a Acott, podle kterých ve škále chybí zejména přijetí intrinsické hodnoty přírody a morálních povinností člověka k př́rodě. Podle nich v současnosti "většina lidí zastává hodnoty podobné těm, popsaným v NEP." Důvodem podle autorů může být posun postojů ve společnosti od sedmdesátých let, ovlivněný širokou medializací problémů životního prostředí. Autoři také upozorňují na to, že verbálně zastávané postoje nemusí odrážet skutečně zastávané hodnoty (2000).

V České republice byl NEP v původní či modifikované podobě použit ve třech větších výzkumných projektech. V letech 1993 a 2000 provedl opakovaný výzkum ekogramotnosti Sociologický ústav Akademie věd České republiky. V průzkumu byl NEP využit v upravené podobě. Podle autorů šlo o "jakousi kvazi NEP škálu" (Soukup, 2001, s. 19). Podle výsledků došlo v České republice od roku 1993 k poklesu ochoty obětovat se ve prospěch životního prostředí (platit vyšší daně a ceny, snížit svoji životní úroveň), současně k nárůstu proenvironmentálního chování (zejména třídění odpadů). V oblasti občanských aktivit nebyla zaznamenána žádná změna. Environmentální chování je typické pro starší obyvatele, občanské aktivity $v$ oblasti životního prostředí pro mladší. Byl zaznamenán negativní vztah mezi znalostmi a chováním (lidé, kteří toho o životním prostředí vědí více, se chovají k životnímu prostředí méně šetrně) (Soukup, 2001).

V roce 2006 byly publikovány výsledky výzkumu odcizování člověka přírodě řešitelským týmem Zájmové sdružení Toulcův dvůr. Průzkum probíhal v letech 2004-2005 (Strejčková, 2006). Součástí projektu byl i průzkum Marka Fraňka Výzkum antropocentrických a biocentrických postojů k prírodě v české populaci (Franěk, 2006). V průzkumu byl použit van den Bornův dotazník vycházející z NEP, který je zde rozšiřuje o další položky. Podle průzkumu převládají v české populaci proenvironmentální postoje: ve vztahu k prírodě model označený jako "strážce přírody", na druhém místě model „aktivní partner přírody”.

S obrazem proenvironmentálních postojů české veřejnosti korespondují i průzkumy Centra pro výzkum veřejného mínění z června 2006, vycházející z jiné metodiky. Podle 
nich se většina obyvatel České republiky zajímá o informace o životním prostředí a uvědomuje si závažnost ekologických problémů. Respondenti většinou třídí odpad a zhruba polovina doma šetří vodou a energií, neomezují ale jízdy automobilem, nekupují výrobky šetrnější k životnímu prostředí a nejsou ochotni věnovat část přijmů na ochranu životního prostředí (např. formou ekologické daně). Příliš se neúčastní brigád na ochranu prírody a téměř vưbec se nejsou ochotni angažovat formou petic, demonstrací či finanční podpory občanských sdružení (Samanová, 2006a; Samanová, 2006b).

\section{Ekologická gramotnost na školách}

Měření ekologické gramotnosti na školách je jedním ze základních indikátorů úspěšnosti environmentální výchovy. Přestože v České republice nemá př́liš velikou tradici, ze zahraničí je možné uvést několik př́kladů, zpracovaných podle různých metodik. Např́klad v letech 2000-2001 probíhalo v Irsku rozsáhlé měření efektivity projektu Green School (projekt probíhá i $v$ České republice, kde jej pod názvem Ekoškola řídí sdružení TEREZA). Projekt měl dvě části: v jedné byla vyhodnocována produkce odpadu na školách s různou mírou zapojení do projektu, ve druhém byly srovnávány znalosti, postoje a jednání dětí ze škol dlouhodobě zapojených (resp. těch, které získaly ocenění, tzv. Zelenou vlajku) a škol nezapojených. Oba průzkumy ukázaly vyšší míru proenvironmentálních postojů a jednání u škol se Zelenou vlajkou, současně srovnatelnou míru znalostí o životním prostředí (O’Mahony; Fitzgerald, 2001).

V České republice proběhl průzkum ekogramotnosti zaměřený na žáky základních a středních škol v roce 2001 v rámci týmu Kulich-Dobiášová. Do průzkumu bylo zahrnuto 51 základních i středních škol, zpracováno bylo 2000 dotazníků. Průzkum ukázal malou míru proenvironmentálních postojů i znalostí žáků, neznalost místní prírody i antropocentrické postoje. Výsledky přitom ukázaly zajímavou nekonzistenci: větší část žáků sice odmítla tvrzení, že člověk je pánem tvorstva, naprostá většina ale souhlasila s názorem, že chránit je třeba především užitečné živočichy a rostliny. Jestliže se s názorem, že člověk je pánem tvorstva nejméně identifikovali žáci šestých tříd, "s vzrůstajícím věkem žáků míra identifikace s panským postojem vzrůstala." Naopak, s názorem „chránit je třeba především užitečné druhy" souhlasili nejvíce žáci šestých tříd ZŠ, žáci devátých tříd a čtvrtých tříd SŠ významně méně (Kulich; Dobiášová, 2003).

Výsledky vedou k otázkám, které se promítly i do formulace hypotéz tohoto průzkumu: zvyšuje se s léty školní docházky míra proenvironmentálních postojů a jednání žáků či nikoliv? Jsou postoje žáků spíše antropocentrické, jak naznačuje průzkum KulichDobiášová (Kulich; Dobiášová, 2003), nebo neantropocentrické, jak ukazují průzkumy většinových postojů obyvatel České republiky (Franěk, 2006; Samanová, 2006; Samanová, 2006)?

Cíle environmentální výchovy pro středoškolské vzdělávání byly zatím v rámci probíhající školní reformy zformulovány pouze pro gymnázia a gymnázia s rozšířenou sportovní prípravou. Nyní se pokusíme porovnat kompetence v oblasti environmentální výchovy podle připravovaného RVP pro gymnázia s postoji NEP (Cordano; Welcomer; Scherer, 2003; Rámcový vzdělávací program pro gymnázia, 2006). 
Tabulka 1. Porovnání kompetencí v oblasti environmentální výchovy podle připravovaného RVP pro gymnázia s postoji NEP

\begin{tabular}{|c|c|}
\hline $\begin{array}{l}\text { Cílové postoje a hodnoty environmentální } \\
\text { výchovy podle RVP pro gymnázia }\end{array}$ & NEP/DSP \\
\hline \multirow{5}{*}{$\begin{array}{l}\text { 1. Uvědomovat si výlučné postavení } \\
\text { člověka v př́rodním systému a jeho } \\
\text { odpovědnost za další vývoj na planetě. }\end{array}$} & Ekologická krize \\
\hline & $\begin{array}{l}\text { 1. Budeme-li pokračovat dál stejným } \\
\text { směrem, brzy budeme čelit velké ekologické } \\
\text { katastrofě (NEP) }\end{array}$ \\
\hline & $\begin{array}{l}\text { 2. Lidé těžce poškozují životní prostředí } \\
\text { (NEP) }\end{array}$ \\
\hline & $\begin{array}{l}\text { 9. Takzvaná ekologická krize, které čelíme, } \\
\text { je často přehnaně zveličována (DSP) }\end{array}$ \\
\hline & Antiantropocentrismus \\
\hline \multirow{3}{*}{$\begin{array}{l}\text { 2. Pochopit, že člověk z hlediska své } \\
\text { existence musí využívat zdrojư ve svưj } \\
\text { prospěch, ale tak, aby nedošlo } \\
\text { k nenávratnému poškození životního } \\
\text { prostředí. }\end{array}$} & $\begin{array}{l}\text { 3. Lidé byli stvořeni, aby vládli zbytku } \\
\text { př́rody (DSP) }\end{array}$ \\
\hline & $\begin{array}{l}\text { 4. Lidé mají právo upravovat přírodní } \\
\text { prostředí podle svých potřeb (DSP) }\end{array}$ \\
\hline & Neodlučitelnost \\
\hline \multirow{7}{*}{$\begin{array}{l}\text { 3. Uvědomit si, že k ochraně prírody } \\
\text { mưže napomoci každý jedinec svým } \\
\text { ekologicky zodpovědným prístupem } \\
\text { k běžným denním činnostem. } \\
\text { 4. Vnímat místo, ve kterém žije, } \\
\text { a změny, které v něm probíhají, a cítit } \\
\text { odpovědnost za jeho další vývoj, a to nejen } \\
\text { z hlediska životního prostředí. }\end{array}$} & $\begin{array}{l}\text { 5. Lidská vynalézavost zajistí, že nikdy } \\
\text { neučiníme Zemi neobyvatelnou (DSP) }\end{array}$ \\
\hline & $\begin{array}{l}\text { 7. Navzdory našim schopnostem jsme stále } \\
\text { podřízeni zákonùm prírody (NEP) }\end{array}$ \\
\hline & Rovnováha \\
\hline & $\begin{array}{l}\text { 6. Lidské zásahy do přírody vedou často ke } \\
\text { katastrofálním dopadưm (NEP) }\end{array}$ \\
\hline & $\begin{array}{l}\text { 8. Rovnováha v prírodě je dost silná na to, } \\
\text { aby zvládla vliv moderní průmyslové } \\
\text { společnosti(DSP) }\end{array}$ \\
\hline & Meze růstu \\
\hline & $\begin{array}{l}\text { 10. Země je jako kosmická lod's omezeným } \\
\text { prostorem a zdroji (NEP) }\end{array}$ \\
\hline
\end{tabular}

Ze srovnání je patrná jistá mimoběžnost. Chápání lidského postavení v prírodě jako „výlučného" i znění celé první kompetence RVP odpovídá antropocentrickému chápání postavení člověka, resp. chápání člověka jako "správce" či "strážce přírody". Nejblíže má k třetímu postoji NEP/DSP, vyjadřujícího dominantní společenské paradigma člověka jako "vládce prírody". S tím koresponduje i druhý postoj, který ale připouští riziko "nenávratného poškození životního prostředí", které je v NEP akcentováno v prvním a ve druhém bodě.

Třetí ani čtvrtý postoj RVP nemají v NEP/DSP ekvivalent.

Je zřejmé, že proenvironmentální postoje definované nejznámějším nástrojem pro měření proenvironmentálních postojů, NEP, přiliš nekorespondují s cílovými postoji absolventů středních škol podle připravovaného kutikulárního dokumentu. Na druhé straně je validita NEP podrobována značné kritice. Je proto relevantní pokusit se ověřovat ekogramotnost studentů středních škol nástrojem, který by kombinoval NEP s dalšími pomocnými škálami a bral v potaz i cílové postoje a hodnoty podle RVP. 


\section{Metodika průzkumu}

Problematikou se zabýval průzkum, který byl proveden v květnu roku 2006 v prvních a čtvrtých ročnících Střední průmyslové školy strojní a elektrotechnické a Vyšší odborné školy Liberec a Střední průmyslové školy strojnické (SPŠS) a Vyšší odborné školy Chrudim. Vzorek tvořilo 183 studentů (171 mužù a 12 žen) ve věku od 15 do 21 let. Žáků první třídy přitom bylo 91, žáků čtvrtého ročníku 92. Průzkum byl realizován $v$ rámci bakalářské práce studenta doplňujícího pedagogického studia na Fakultě pedagogické Technické univerzity v Liberci, Petra Štěpánka (sběr dat a počítačové zpracování), vedoucí práce byl Jan Činčera (návrh zadání a metodiky, zpracování článku). Průzkumu předcházel pilotní předvýzkum provedený v březnu 2006 mezi studenty čtvrtého ročníku Střední pedagogické školy a Gymnázia Jeronýmova v Liberci. Cílem práce bylo ověřit následující hypotézy:

H1: Studenti 4. ročníků SPŠS zastávají častěji proenvironmentální postoje než studenti 1. ročníků.

H2: Menšina studentů SPŠS zastává proenvironmentální postoje. jednání.

H3: Menšina studentů SPŠS preferuje ve svém životě environmentálně příznivé částí:

Průzkum byl proveden dotazníkovou formou. Dotazník se skládal z následujících

1. Revidovaná NEP/DSP škála.

2. Rozšiřující škála proenvironmentálních postojů.

3. Škála zvažovaného proenvironmentálního jednání.

4. Rozšiřující škála proenvironmentálního jednání.

5. Porozumění provázanosti - anketní otázka.

\section{Revidovaná NEP/DSP škála}

V průzkumu byla použita varianta NEP publikovaná v analýze Cordana, Scherera a Welcomera (Cordano; Welcomer; Scherer, 2003). Škála měří na Likertově stupnici (použita sedmibodová stupnice) míru souhlasu s tvrzeními, charakteristickými pro NEP či DSP:

1. Budeme-li pokračovat dál stejným směrem, brzy budeme čelit velké ekologické katastrofě.

2. Lidé těžce poškozují životní prostředí.

3. Lidé byli stvořeni, aby vládli zbytku prírody.

4. Lidé mají právo upravovat přírodní prostředí podle svých potřeb.

5. Lidská vynalézavost zajistí, že nikdy neučiníme Zemi neobyvatelnou.

6. Lidské zásahy do přírody vedou často ke katastrofálním dopadům.

7. Navzdory našim schopnostem jsme stále podřizeni zákonům prírody.

8. Rovnováha $v$ prírodě je dost silná na to, aby zvládla vliv moderní průmyslové společnosti. 
9. Tak zvaná ekologická krize které čelíme, je často přehnaně zveličována.

10. Země je jako kosmická lod's omezeným prostorem a zdroji.

\section{Rozšiřující škála proenvironmentálních postojů}

$\mathrm{Na}$ základě doporučení La Trobe a Acotta (2000) i cílových postojů studentů gymnázií podle RVP byla škála postojů NEP/DSP rozšířena o doplňující otázky. Autorem škály je Jan Činčera, škála byla poprvé vyzkoušena v rámci předvýzkumu na Střední pedagogické škola a gymnáziu Jeronýmova v březnu 2006. Cílem bylo ověřit rovinu vztahu respondentů k místu, antropocentrickou či neantropocentrickou názorovou orientaci, přijetí morálního závazku za své jednání, souhlas s hlubinně ekologickým konceptem vitálních potřeb a uvědomění si souvislostí mezi lokální a globální dimenzí.

11. Zviŕata a rostliny mají stejná práva existovat, jako lidé.

12. Mám rád místo ve kterém žiji.

13. Problémy a príběhy lidí mimo moje vlastní bydliště jsou vzdálené a v podstatě mě nijak neovlivňují.

14. Současná generace má morální závazky vůči budoucím generacím.

15. Přírodní zdroje by měly být využívány spiše pro uspokojení základních životních potřeb než pro materiální blahobyt.

16. Moje jednání nemá žádný faktický vliv na události mimo místo, kde žiji.

\section{Škála zvažovaného proenvironmentálního jednání}

Škála zvažovaného proenvironmentálního jednání (PBS) byla převzata z práce Cordana, Scherera a Welcomera (2003). PBS měří ochotu respondentů k různým činnostem, chápaných jako pozitivní ve vztahu k životnímu prostředí.

17. Podepsal bych petici na podporu prísnějších zákonů na ochranu životního prostředí.

18. Účastnil bych se protestní akce proti firmě, která poškozuje životní prostředí.

19. Plánuji zúčastnit se akce organizované environmentální organizací.

20. Rozšiřoval bych informace vydané environmentální organizací mezi moji rodinu a prátele.

\section{Rozšiřující škála proenvironmentálního jednání}

Cílem této škály bylo získat výpovědi o skutečném jednání respondentů. Respondenti měli uvést četnost jednotlivých činností za posledních šest měsíců v rozmezí: "Vícekrát-jednou-vůbec-nevím". Škála zachycuje zájem respondenta o př́rodu, zájem o získávání informací, ochotu finančně přispívat, občanskou angažovanost, spotřebitelské chování a snahu o snižování své ekologické stopy. Autorem škály je Jan Činčera.

Za posledních šest měsíců jsem...

21. Navštívil/-a prírodu ve svém okolí.

22. Navštívil/-a přírodu $v$ jiné zemi.

23. Přečetl/-a jakoukoliv publikaci nebo informační zdroj o životním prostředí.

24. Finančně přispěl/-a na ochranu životního prostředí. 
25. Finančně přispěl/-a na charitativní účely.

26. Podepsal/-a petici požadující lepší ochranu životního prostředí nebo se jinak písemně vyjádřil pro tento požadavek.

27. Koupil/-a výrobek s ekoznačkou.

28. Koupil/-a si dražší výrobek kvůli tomu, že byl šetrnější k životnímu prostředí.

29. Třídil/-a doma odpad.

30. Využil/-a právo na informace pro otázky související s životním prostředím.

\section{Porozumění provázanosti - anketní otázka}

Poslední část průzkumu byla zaměřena na ověření schopnosti respondentů kritickým myšlením propojit postoje s jednáním. Ověřovaným postojem se stalo porozumění provázanosti světa. Porozumět provázanosti světa a souvislostem mezi svým jednáním a jeho dopady na společnost i životní prostředí jsou jednou z nejdůležitějších kompetencí rozvíjených environmentální výchovou. Podle připravovaného Rámcového vzdělávacího programu pro gymnázia má žák „pochopit velkou provázanost faktorů ekologických s faktory ekonomickými a sociálními a být schopen vybrat optimální řešení v reálných situacích." Měl by si také uvědomit, že "k ochraně přírody může napomoci každý jedinec svým ekologicky zodpovědným přístupem k běžným denním činnostem" (Rámcový vzdělávací program pro gymnázia, 2006). Vědomí provázanosti je prvním ze tří hlavních cílů environmentální výchovy podle Tbiliské deklarace (", posílit naše vědomí a porozumění ekonomické, sociální a ekologické provázanosti v městských i venkovských oblastech")(Tbilisi Declaration, 2007), globální výchovy, výchovy o Zemi a vlastně všech důležitějších proudů environmentální výchovy. Velmi zretelně je porozumění provázanosti formulováno Fritjofem Caprou (1999). Podle něj patří k hlavním cílům environmentální výchovy, aby děti pochopily, že nic nežije izolovaně, že život je vždy vztahování k ostatním v procesu vzájemné závislosti. Schopnost studenta porozumět provázanosti na prríkladě souvislostí mezi svým jednáním a jeho širšími sociálními, ekonomickými i environmentálními dopady je proto kritickým indikátorem ekogramotnosti.

V dotazníku byla použita otevřená otázka anketního typu: „Představ si, že si chceš koupit nový MP3 přehrávač. Jakým způsobem takové rozhodnutí ovlivní životní prostředí (pokud má nějaký vliv)? (napiš svůj názor ve 3-5 větách):". Je zřejmé, že zakoupením jediného výrobku ovlivníme životní prostředí jen málo. Na druhou stranu, podstatou uvědomění si své provázanosti se životním prostředí je právě vědomí odpovědnosti za své spotřebitelské chování.

\section{Výsledky průzkumu}

V dalším textu jsou stručně a přehledně přiblíženy hlavní výsledky průzkumu ekologické gramotnosti studentů středních odborných škol.

\section{Revidovaná NEP/DSP škála}

Respondenti odpovídali na škále 1 (nesouhlasím) - 7 (souhlasím). Obrázek 1 ukazuje průměrnou hodnotu odpovědí. Statistická významnost rozdílu v odpovědích prvních a čtvrtých ročníků, která byly vyhodnocována v H1, byla ověřována pomocí párového T-testu. Čísla otázek odpovídají pořadí v dotazníku. Výsledky jsou zaokrouhleny na dvě desetinná místa. Vzhledem k malému počtu respondentek nebyly rozdíly mezi muži a ženami vyhodnocovány. 


\section{Obrázek 1. Souhlas s postoji nového environmentálního paradigmatu}

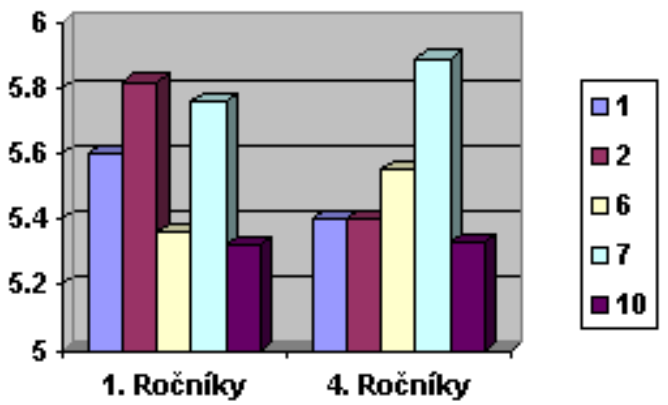

1. Budeme-li pokračovat dál stejným směrem, brzy budeme čelit velké ekologické katastrofě.

2. Lidé těžce poškozují životní prostředí.

6. Lidské zásahy do přírody vedou často ke katastrofálním dopadům.

7. Navzdory našim schopnostem jsme stále podřízeni zákonům přírody.

10. Země je jako kosmická lod's omezeným prostorem a zdroji.

\section{Obrázek 2. Souhlas s postoji dominantního společenského paradigmatu}

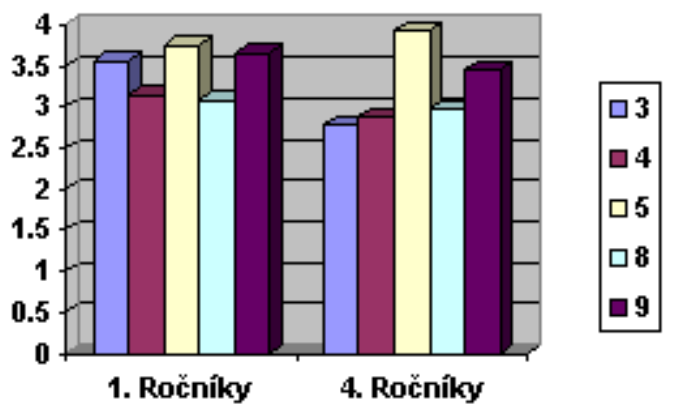

3. Lidé byli stvořeni, aby vládli zbytku přírody.

4. Lidé mají právo upravovat přírodní prostředí podle svých potřeb.

5. Lidská vynalézavost zajistí, že nikdy neučiníme Zemi neobyvatelnou.

8. Rovnováha $v$ prírodě je dost silná na to, aby zvládla vliv moderní průmyslové společnosti.

9. Takzvaná ekologická krize, které čelíme, je často přehnaně zveličována. 
Z výsledků je patrné, že studenti středních odborných škol většinou souhlasí s postoji nového environmentálnímu paradigmatu. Nejrozhodněji souhlasí s tvrzením o neodlučitelnosti člověka od přírody („Navzdory našim schopnostem jsme stále podřizeni zákonům prírody."), naopak nejmenší míru souhlasu vyjadřují k tvrzení o omezenosti zdrojů planety ("Země je jako kosmická lod' s omezeným prostorem a zdroji."). Rozdíly mezi prvním a čtvrtým ročníkem nejsou př́liš veliké. Statisticky významný rozdíl se objevil pouze u otázek č. 2 a č. 3 . S tvrzením č. 2 odpovídající NEP ("Lidé těžce poškozují životní prostředí.") překvapivě častěji souhlasí studenti prvního ročníku. S tvrzením č. 3 odpovídajícímu DSP ("Lidé byli stvořeni, aby vládli zbytku přírody.") souhlasí také více studentů prvního ročníku. Postoje odpovídající dominantnímu společenskému paradigmatu studenti spíše odmítají, nebo jsou k nim nerozhodní. Nerozhodnost vyjádřili studenti obou ročníků k tvrzení "lidská vynalézavost zajistí, že nikdy neučiníme Zemi neobyvatelnou". Nerozhodnost je také patrná u tvrzení „tak zvaná ekologická krize, které čelíme, je často přehnaně zveličována".

\section{Rozšiřující škála proenvironmentálních postojů}

Respondenti odpovídali na škále 1 (nesouhlasím) - 7 (souhlasím). Obrázek 3 ukazuje průměrnou hodnotu odpovědí. Čísla otázek odpovídají pořadí v dotazníku. Otázky č. 11,12 , 14 a 15 reprezentují rozšíření nového environmentálního paradigmatu o dimenze neantropocentrismu, vztahu k místu, morální odpovědnosti a dobrovolné skromnosti (koncept vitálních potřeb). Otázky č. 13 a č. 16 reprezentují rozšíření dominantního společenského paradigmatu.

\section{Obrázek 3. Rozšiřující škála proenvironmentálních postojů}

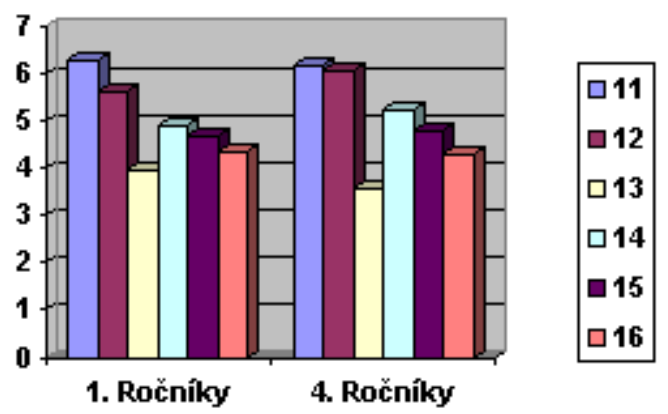

11. Zvírata a rostliny mají stejná práva existovat, jako lidé.

12. Mám rád /-a místo ve kterém žiji.

13. Problémy a príběhy lidí mimo moje vlastní bydliště jsou vzdálené a $v$ podstatě mě nijak neovlivňují.

14. Současná generace má morální závazky vưči budoucím generacím.

15. Přírodní zdroje by měly být využívány spíše pro uspokojení základních životních potřeb než pro materiální blahobyt.

16. Moje jednání nemá žádný faktický vliv na události mimo místo, kde žiji.

Studenti souhlasí s postoji reprezentujícími rozšířené nové environmentální paradigma i rozšiřené dominantní společenské paradigma. Nejmenší míru souhlasu vyjádřili ke tvrzení „problémy a př́běhy lidí mimo moje vlastní bydliště jsou vzdálené a v podstatě mě nijak neovlivňují". Spíše souhlasí i se souvisejícím výrokem "moje jednání 
nemá žádný faktický vliv na události mimo místo, kde žiji". Větší míra souhlasu byla zaznamenána u výrokư podporujících rozšiřené nové environmentální paradigma. Největší míru souhlasu studenti vyjádřili u otázek č. 11 "zvírata a rostliny mají stejná práva existovat, jako lidé" a č. 12 „mám rád místo ve kterém žiji”. Souhlas s otázkou č. 11 by naznačoval neatropocentrickou názorovou orientaci studentů. To odpovídá i nesouhlasnému hodnocení tvrzení č. 3 a č. 4 . V souvislosti s tím je ale třeba upozornit na významně menší míru souhlasu s tvrzením č. 15 „přírodní zdroje by měly být využívány spíše pro uspokojení základních životních potřeb než pro materiální blahobyt", indikujícím hlubinně ekologický koncept vitálních potřeb. Je možné, že studenti deklarují postoj, který považují za společensky preferovaný, jejich souhlas se ale snižuje, pokud jsou konfrontováni s jeho logickými důsledky. Rozdíly mezi prvními a čtvrtými ročníky nejsou statisticky významné.

\section{Škála zvažovaného proenvironmentálního jednání}

Respondenti odpovídali na škále 1 (nesouhlasím) - 7 (souhlasím). Obrázek 4 ukazuje průměrnou hodnotu odpovědí. Čísla otázek odpovídají pořadí v dotazníku.

\section{Obrázek 4. Škála zvažovaného proenvironmentálního jednání}

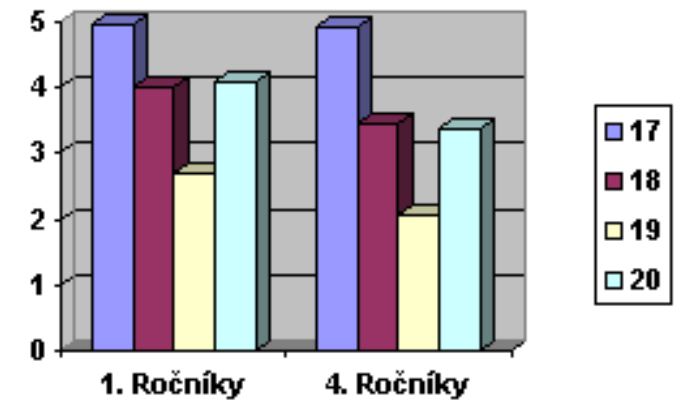

17. Podepsal bych petici na podporu přísnějších zákonů na ochranu životního prostředí.

18. Účastnil bych se protestní akce proti firmě, která poškozuje životní prostředí.

19. Plánuji zúčastnit se akce organizované environmentální organizací.

20. Rozšiřoval bych informace vydané environmentální organizací mezi moji rodinu a přátele.

Studenti vyjádřili největší ochotu podepsat petici na podporu přísnějších zákonů. Míra ochoty zapojit se do dalších typů akcí je významně menší, přestože se pohybuje na průměru či lehce pod ním. Většina studentů neuvažuje o zapojení se do akcí nevládních organizací. Z výsledků je patrný rozdíl mezi prvními a čtvrtými ročníky u tvrzení č. 19 a č. 20. Zatímco ochota podepisovat petice zưstává u obou skupin stejná, studenti prvních ročníků vyjadřují větší ochotu zapojit se do proenvironmentálních aktivit, než studenti čtvrtých ročníků. Jsou také ochotnější rozšiřovat informace o životním prostředí.

\section{Rozšiřující škála proenvironmentálního jednání}

V této části prezentujeme odpovědi ke každé otázce ve zvláštním grafu. Rozdíly mezi muži a ženami nebyly opět brány $v$ potaz. Čísla otázek odpovídají pořadí v dotazníku. Za posledních šest měsíců jsem... 
Obrázek 5. Navštívil/-a přírodu ve svém okolí. (Otázka č. 21)

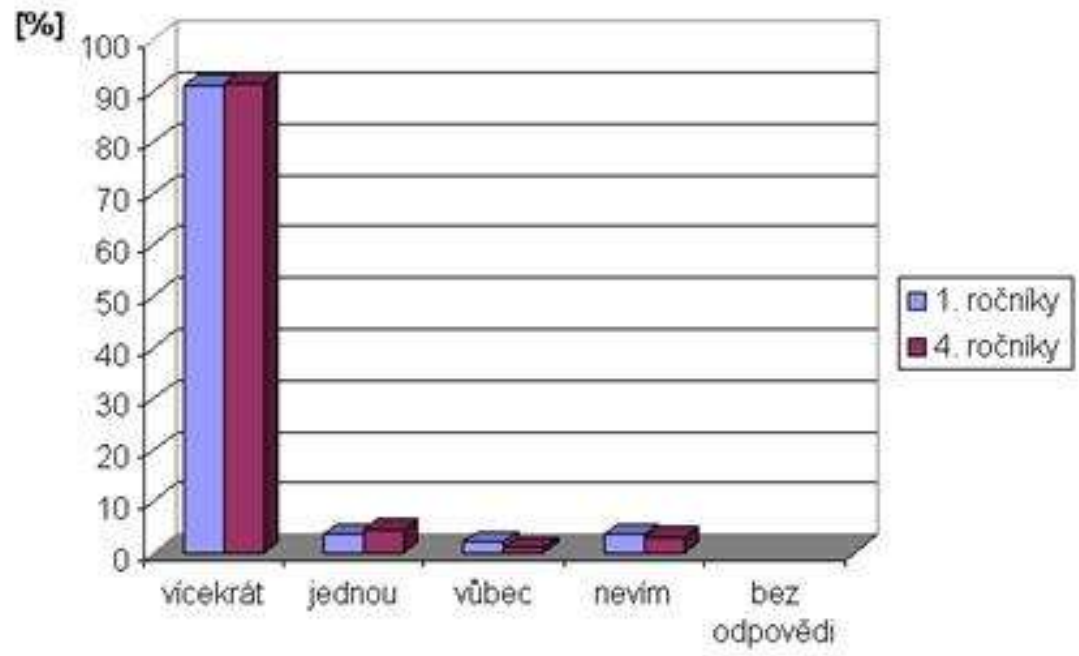

Studenti opakovaně navštěvují prírodu ve svém okolí, oba ročníky ve shodné míře.

Obrázek 6. Navštívil/-a přírodu v jiné zemi. (Otázka č. 22)

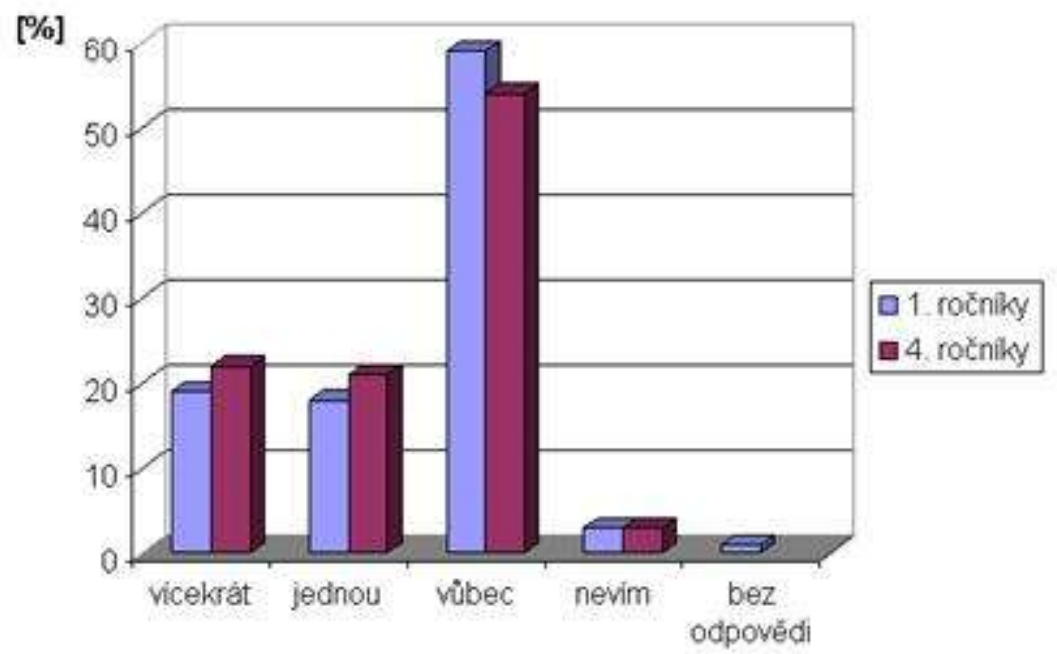

Většina studentů nenavštívila $v$ posledním půlroce př́rodu $v$ cizí zemi. To na druhé straně může znamenat pouze nedostatek príležitostí $v$ období školního roku. Rozdíly mezi ročníky nejsou významné. 
Obrázek 7. Přečetl/-a jakoukoliv publikaci nebo informační zdroj o životním prostředí. (Otázka č. 23)

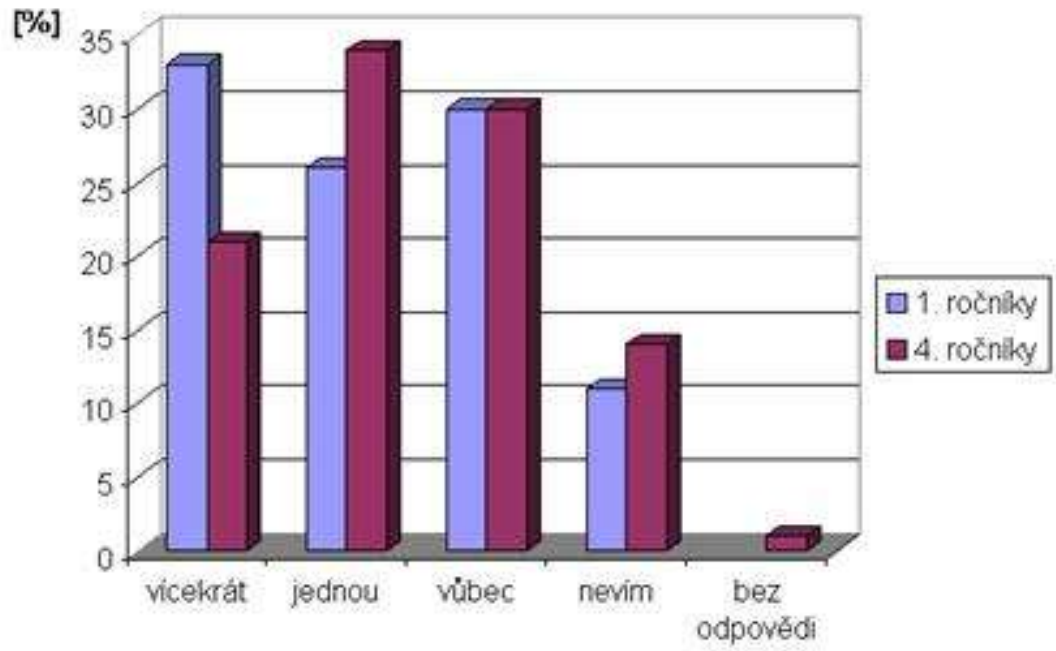

Třetina respondentů nepřečetla žádnou publikaci, zhruba dvě třetiny jednu či více publikací či informačních zdrojů. Přestože podíl studentů, kteří čtou publikace o životním prostředí je mezi oběma ročníky zhruba stejný, studenti prvních ročníků častěji čtou více publikací. To naznačuje vyšší zájem o otázky životního prostředí, než u jejich starších spolužáků. Rozdíl ale není statisticky významný.

\section{Obrázek 8. Finančně přispěl/-a na ochranu životního prostředí. (Otázka č. 24)}

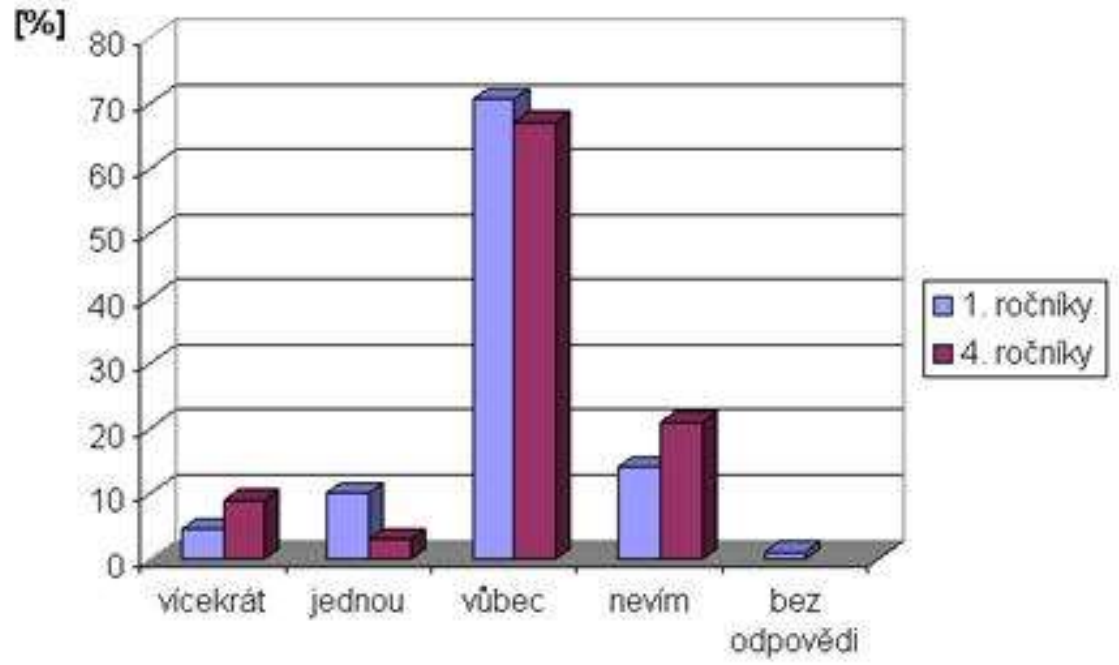

Většina studentů $v$ posledním půlroce nepřispěla na ochranu životního prostředí. Celkové procento těch, kteři přispěli, je zhruba stejné u prvního i čtvrtého ročníku. Rozdíly mezi oběma skupinami jsou malé, přispívající studenti jsou pravděpodobně spiše izolovaní jedinci se zájmem o životní prostředí. 
Obrázek 9. Finančně přispěl/-a na charitativní účely. (Otázka č. 25)

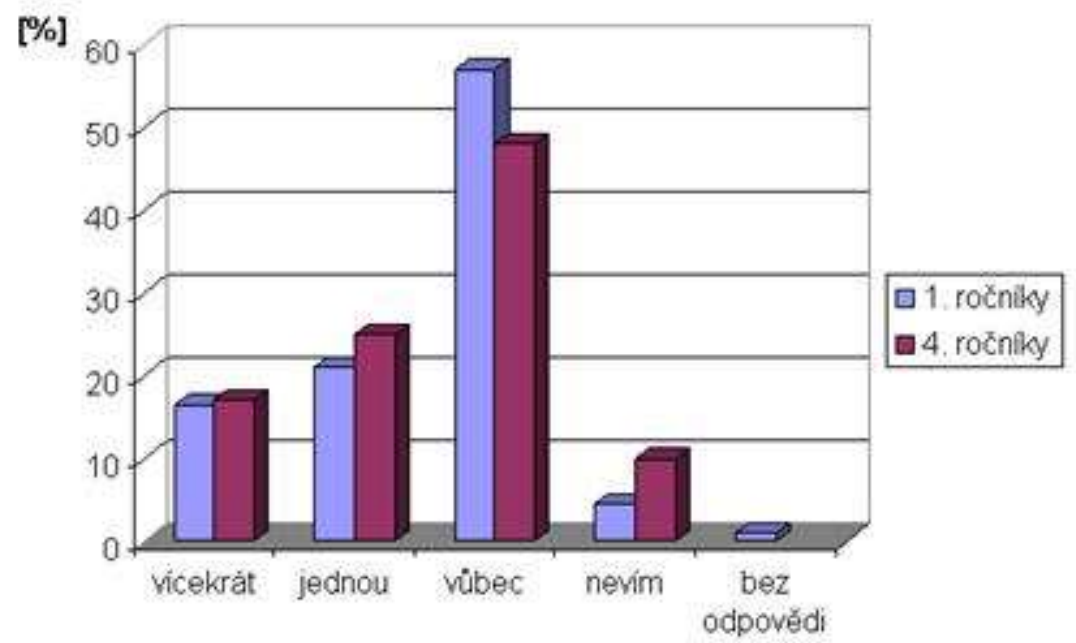

Přestože většina studentů nepřispívá ani na charitativní účely, je procento těch, kteř́ jednou či vícekrát přispěli významně vyšší, než u sbírek na ochranu přírody. To př́liš nepotvrzuje neantropocentrickou orientaci studentů, deklarovanou $v$ predchozích částech dotazníku. Studenti čtvrtých ročníků přispívají o něco častěji, než studenti prvních ročníků. Rozdíl ale není statisticky významný a mưže souviset i s vyšší finanční soběstačností studentů čtvrtých ročníků.

Obrázek 10. Podepsal/-a petici požadující lepší ochranu životního prostředí nebo se jinak písemně vyjádřil pro tento požadavek. (Otázka č. 26)

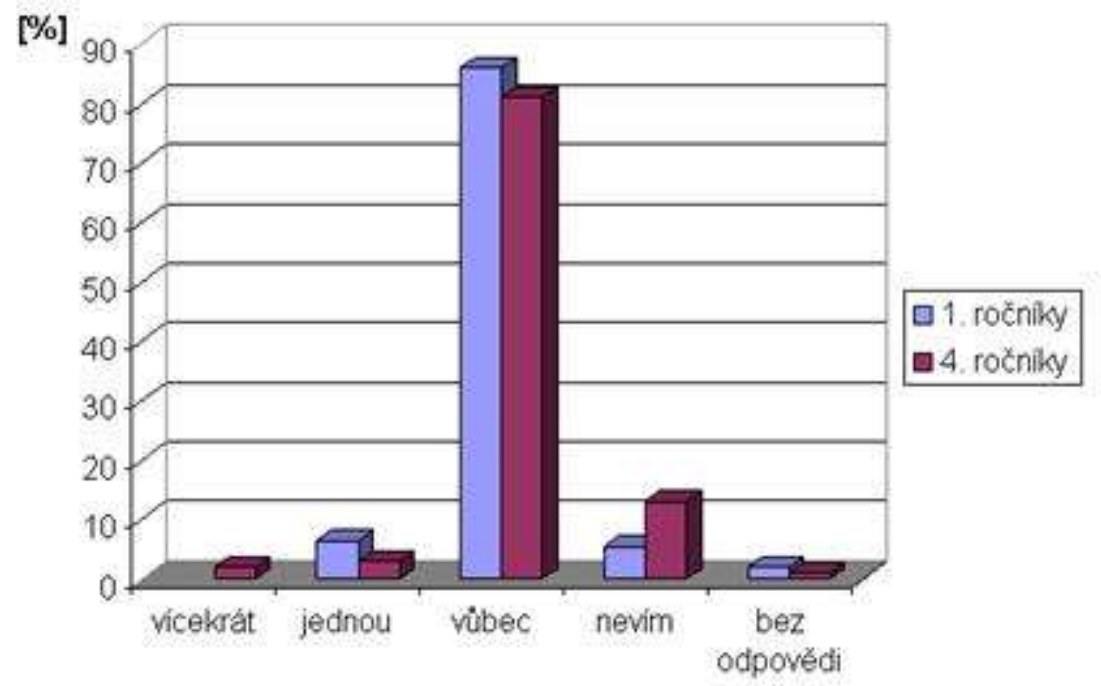

Naprostá menšina studentů podepsala v posledním půlroce alespoň jednou petici týkající se životního prostředí. To kontrastuje s deklarovanou ochotou petice podepisovat, vyjádřenou $\mathrm{v}$ otázce č. 17 . Vzhledem $\mathrm{k}$ tomu, že petice týkajících se problémů životního prostředí je možné podepsat téměř kdykoliv prostřednictvím internetových kampaní nebo při návštěvě místních ekologických organizací, je na místě zpochybnit proaktivní postoj vyjádřený v otázce č. 17. 
Obrázek 11. Koupil/-a výrobek s ekoznačkou. (Otázka č. 27)

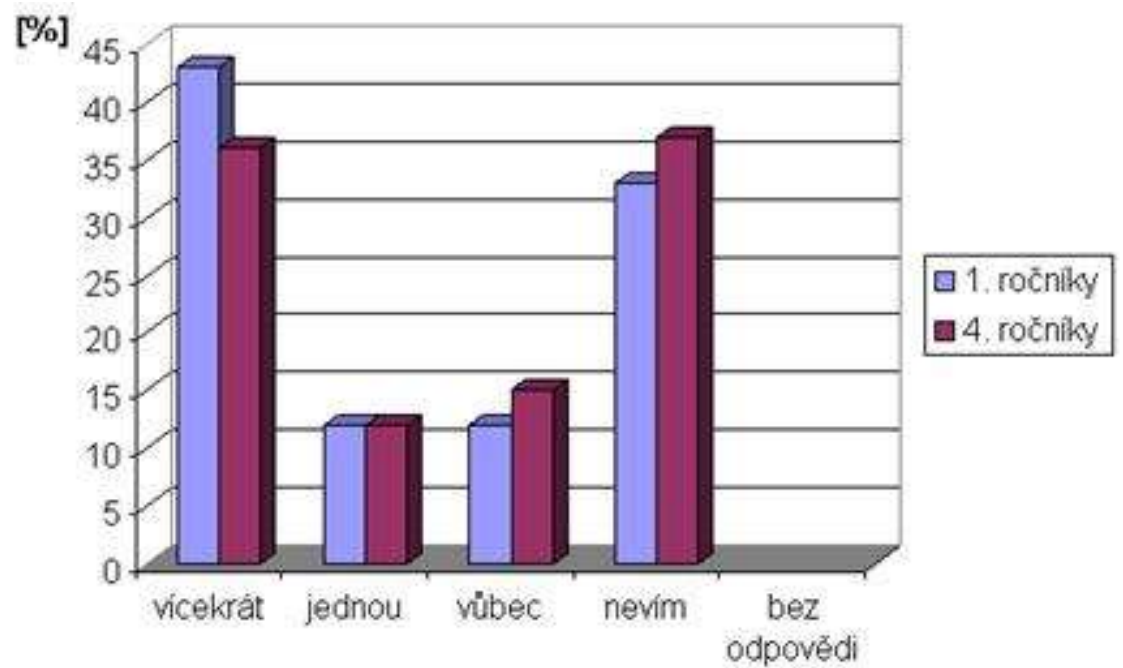

Více než polovina studentů si opakovaně či alespoň jednou koupila výrobek s ekoznačkou. Vysoký podíl respondentů, kteří odpověděli "nevím", naznačuje, že ne všichni studenti jsou schopni výrobky s ekoznačkou poznat nebo si zapamatovat, že tak učinili. Z průzkumu bohužel nevyplývá, zda všichni respondenti, kteří odpověděli „vícekrát" či „jednou", skutečně rozpoznají ekoznačky od ostatních obalových symbolů. O něco častěji si výrobek s ekoznačkou koupili studenti prvních ročníků, rozdíl ale není statisticky významný.

Obrázek 12. Koupil/-a si dražší výrobek kvůli tomu, že byl šetrnější k životnímu prostředí. (Otázka č. 28)

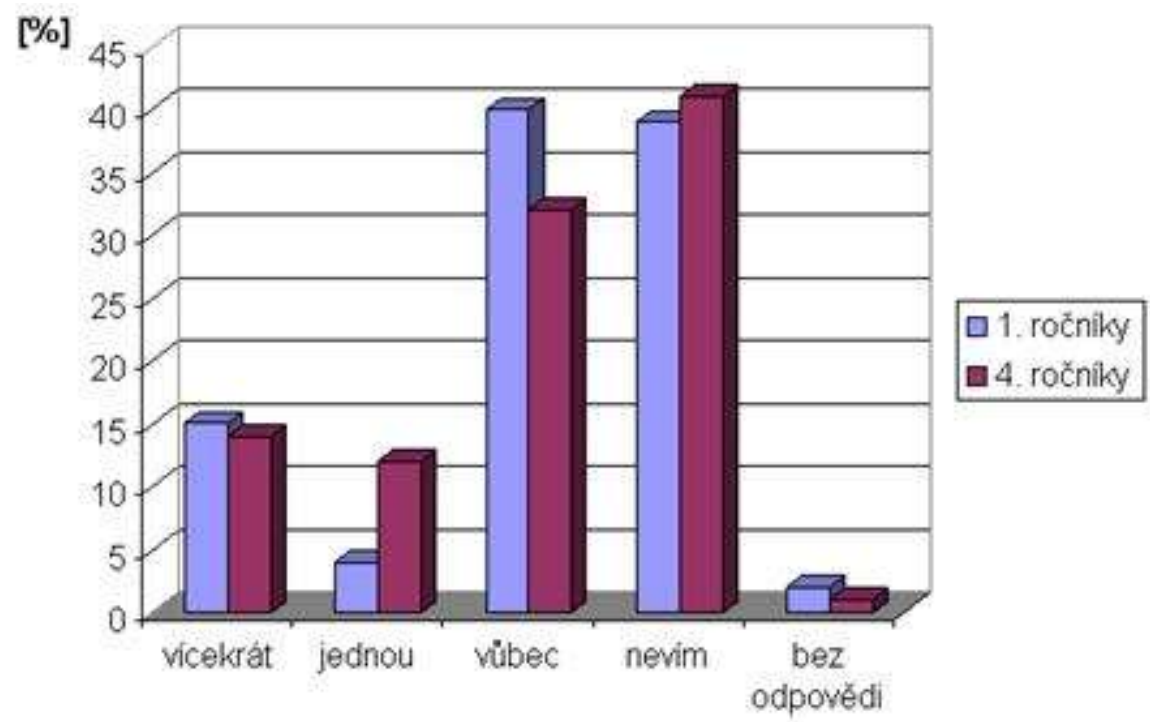

Ochota platit více za ekologicky příznivější výrobky je u obou ročníků na srovnatelně nízké úrovni. Lze říct, že pouze zhruba čtvrtina studentů si v posledním roce koupila dražší, ale ekologicky přínivější výrobek. To kontrastuje s předchozí otázkou. Vzhledem k tomu, že výrobky s ekoznačkou jsou zpravidla dražší, než necertifikované výrobky, je na místě opět zpochybnit výsledky otázky č. 27. Je rovněž zajímavé porovnat výsledky s otázkami 
č. 15 a č. 16. Studenti spíše souhlasí s tvrzením „přírodní zdroje by měly být využívány spíše pro uspokojení základních životních potřeb než pro materiální blahobyt", v běžném životě ale nejsou ochotni "více platit”. To koresponduje se souhlasem s tvrzením "moje jednání nemá žádný faktický vliv na události mimo místo, kde žiji".

Obrázek 13. Třídil/-a doma odpad. (Otázka č. 29)

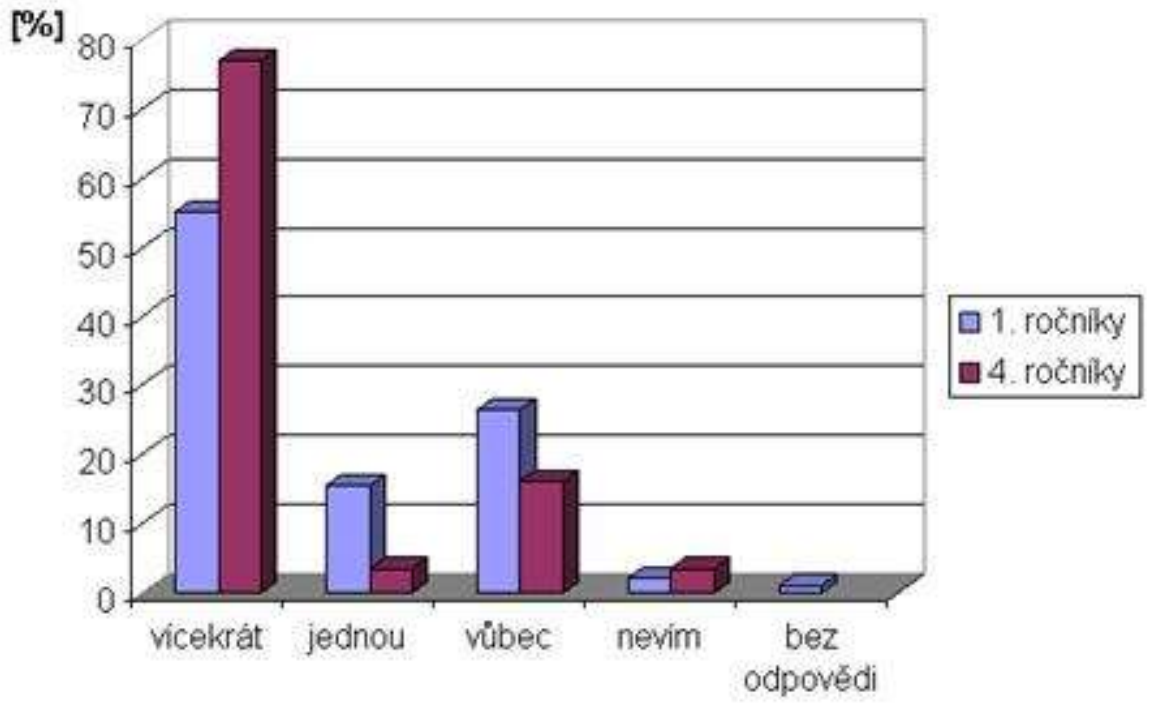

Výsledky ukazují, že třídění odpadu je u studentů běžné, u studentů čtvrtého ročníku významně více, než u studentů prvního ročníku. To může být ovlivněno vyšší mírou samostatnosti u starších studentů.

Obrázek 14. Využil/-a právo na informace nebo se účastnil/-a jednání s úřady o otázkách souvisejících s životním prostředím. (Otázka č. 30)

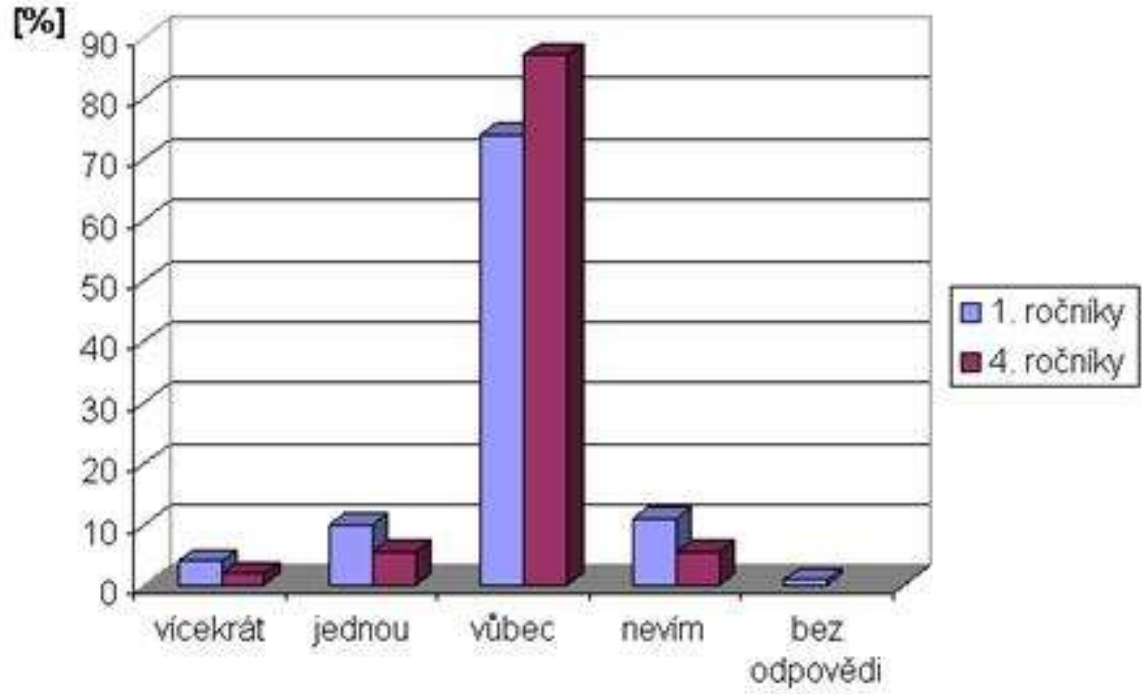


Studenti se naprostou většinou v problémech životního prostředí občansky neangažují, rozdíly mezi ročníky jsou malé. To koresponduje se souhlasem na otázku č. 16: „Moje jednání nemá žádný faktický vliv na události mimo místo, kde žiji.", ale spíše kontrastuje s ochotou k proenvironmentálnímu jednání vyjádřenému v otázkách č. 17 až č. 20.

\section{Porozumění provázanosti - anketní otázka}

K vyhodnocení byla použita metodika kategorizace výsledků. Získané výpovědi byly rozděleny do pěti kategorií. Klíčem byla subjektivně posouzená míra porozumění respondenta životnímu cyklu výrobku a přijetí odpovědnosti za environmentální dopady svého spotřebitelského chování. Vzhledem k malému počtu studentek na školách není v prezentaci výsledku rozlišováno mezi mužskými a ženskými respondenty. Z důvodu nevyhnutelné subjektivnosti takového kategorizování uvádíme v původním znění všechny získané výpovědi.

Kategorie:

1. PIné porozumění. Respondenti, kteří byli zařazeni do této kategorie, rozumí podstatě životního cyklu výrobku. Připouští vliv svého rozhodnutí na životní prostředí a uvádí příklady z různých částí životního cyklu MP3 přehrávače (např. spotřeba surovin, spotřeba energie, emise z dopravy, odpad).

2. Částečné porozumění. Respondenti z této skupiny připouští vliv svého rozhodnutí na životní prostředí. Jako příklad uvádí jeden či dva dopady na životní prostředí nepokrývající více oblastí životního cyklu výrobku.

3. Verbální porozumění. Respondenti z této skupiny souhlasí s tvrzením, že jejich rozhodnutí ovlivní životní prostředí, ale neuvádí žádný konkrétní př́íklad. Omezují se na obecná tvrzení o vlivu člověka na životní prostředí a provázanost současného světa.

4. Neporozumění. Tito respondenti odmítají tvrzení, že by svým rozhodnutím jakkoliv ovlivnili životní prostředí.

5. Bez odpovědi. Poslední skupina respondentů se otázce vyhnula nebo na ní neodpověděla.

Souhrnné výsledky

\section{Obrázek 15. Procentuální rozložení respondentů do jednotlivých kategorií}

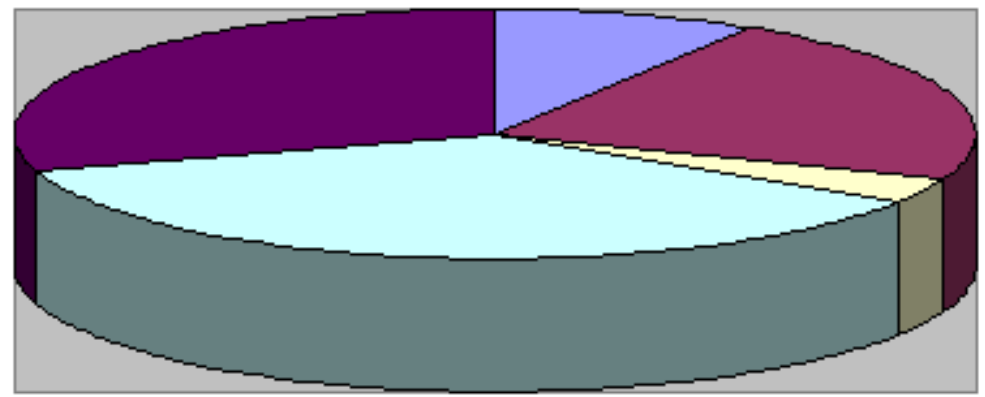

๑PIné $\square$ Částečné $\square$ Verbální $\square$ Heporozumèní $\square$ Bez odpovědi 
Pouhých 9 \% všech respondentů odpovědělo způsobem, který je oprávnil k zařazení do kategorie „plné porozumění". Počet respondentů v obou věkových skupinách byl téměř stejný (8 studentů $v$ každém ročníku). 22 \% respondentů uvedlo částečné odpovědi, zachycující pouze některý z aspektů dopadu na životní prostředí, ve čtvrtém ročníku téměř dvakrát tolik, než v prvním. K nekonkrétním, verbálním, odpovědím se uchýlila $3 \%$ respondentů, 3 z prvních a 7 ze čtvrtých ročníků. Největší skupina, 36 \% studentů, z toho 33 z prvního a 28 ze čtvrtého ročníku, je přesvědčena, že jejich spotřebitelské chování nemá na životní prostředí vliv. Odpovědi se vyhnulo $30 \%$ respondentů, z toho 27 z prvních a 9 ze čtvrtých ročníků.

\section{Obrázek 16. Počty respondentů podle ročníků a kategorií}

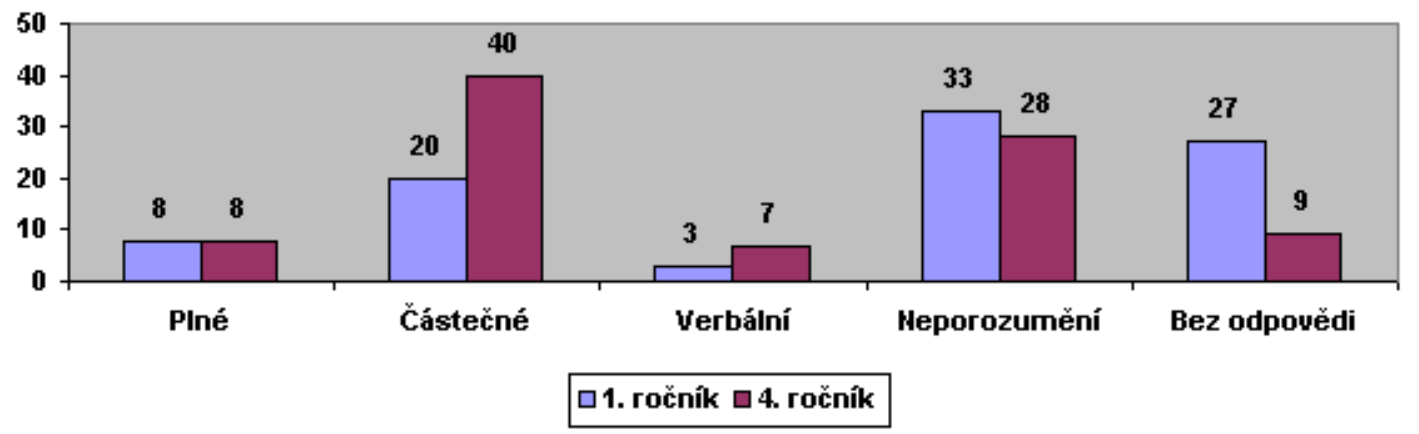

Celkově Ize shrnout, že z množiny studentů středních odborných škol si 31 \% různé míře uvědomuje možnou souvislost mezi svým spotřebitelským chováním a životním prostředím. Tato skupina je z 62,6 \% tvořena studenty čtvrtých ročníků a z 37,3 \% studenty prvních ročníků.

\section{PIné porozumění}

Respondenti $v$ této kategorii si uvědomují, že jejich rozhodnutí má vliv na životní prostředí a jsou schopni jej specifikovat na příkladech z více fází životního cyklu výrobku. Odpovědi studentů čtvrtého ročníku jsou delší a jazykově bohatší, obsahově jsou ale obě skupiny srovnatelné.

První ročníky:

- $\quad$ ŽP ovlivní výrobou. Až doslouží, stane se z něj odpad.

- Těžba ropy $\rightarrow$ zpracování $\rightarrow$ výroba $\rightarrow$ prodej $\rightarrow$ teprve pak můžu mít MP3; znečištění ŽP

- Výroba plast. dílů (ropa, fosilní paliva), baterie, odpad z obalu

- $\quad$ MP3 potřebuje el. energii - musí se vyrobit (těžba).

- $\quad$ Plast $\rightarrow$ ropa $\rightarrow$ poškození.

- Když si ho pořídím, tak na jeho obal padne pár stromů. Jeho výroba znečistí ovzduší - je z plastu. Až doslouží, tak se bude muset spálit $\rightarrow$ opět znečistí prostředí.

- ŽP ovlivní především jeho výroba a jeho likvidace.

- Určitě ovlivní, ale nevím jak moc. Určitě se musí vše vyrobit, zabalit, dovézt atd. 
Čtvrté ročníky:

- Spotřeba energie a materiálu.

- Pouze koupě ŽP neovlivní. Na výrobu je třeba plast $\rightarrow z$ ropy. Pro provoz baterie, které se musí nějak zlikvidovat a to může ovlivnit žP. Když bych si však MP3 nekoupil, stejně by byl vyroben...

- Energie a spotřebované suroviny byly přetvořeny na plasty (MP3) a ty se hůře vracejí zpět do prírody.

- Musí se nějak vyrobit. Při tom spotřebují energii, která se musí někde získat. Dále se musí dopravit do obchodu, což vyžaduje další energii.

- Stejně, jako rozhodnutí koupit cokoli jiného. Někdo to musí vyrobit a někdo zlikvidovat. $\mathrm{K}$ tomu je potřeba energie a další suroviny.

- Při výrobě $v$ továrně se uvolňuje odpad atd. Při převozu se vypouští výfukové plyny do atmosféry.

- Energie vynaložená na jeho výrobu, dovoz atd. jsou značné. Provoz $\rightarrow$ baterie $\rightarrow$ další ekologická zátěž. Ovšem je to jakýsi životní standard.

- Závisí na pohonu přehrávače - dobíjecí baterie, materiál krytu a jeho výroba, testování MP3 přehrávače na zviŕatech...

\section{Částečné porozumění}

Do této skupiny byl zařazen dvojnásobek respondentů čtvrtých ročníků ve srovnání s prvními. Respondenti většinou uváděli, že se z výrobku stane odpad, který může být nebezpečný a navrhovali nahradit baterie akumulátory. Vzácněji se objevovaly jiné druhy dopadů (rušení přírody, př́nos pro státní rozpočet, spotřeba energie atd.).

První ročníky:

- Jediný dopad by mohl být z nesprávné likvidace galvanických článků (ovlivnění nepatrné).

- Téměř vůbec neovlivní. Určitě bych koupil dobíjecí baterie, které jsou šetrnější $k \check{Z} \mathrm{P}$.

- Až doslouží - odpad.

- Při těžbě ropy se ničí ŽP.

- Nabíjecí baterie méně ovlivňují ŽP.

- Potřeba baterií $\rightarrow$ další odpad $\rightarrow$ je zapotřebí třídit.

- Vliv na ekologii - odpad a jeho třídění (baterie).

- Jako odpad MP3 přehrávač rozhodně škodí.

- Samotný MP3 přehrávač prostředí neovlivňuje. Co však ovlivňuje prostředí jsou baterie, které se do něj kupují.

- Nemá žádný vliv pokud MP3 a baterie nevyhodím mimo odpad.

- Ovlivní to ŽP už při jeho výrobě - vzniká odpad.

- Určitě to ŽP ovlivní dalším odpadem. Pokud budu chtít, tak si ho stejně koupím. 
- Po koupi zahodím obal - poškozuji ŽP. Vyhodím starý - poškozuji ŽP.

- Musí se vyrobit a tím znečistí ŽP.

- Nevím. Asi bych si k němu koupil nabíjecí baterie, abych jich nemusel moc vyhazovat.

- MP3 přehrávač se musí vyrobit a výroba zasáhne do ŽP.

- MP3 přehrávače se vyrábí ve velkém - spotřební zboží. Jednou koupí se nic moc nestane. Zhorší ŽP, hodí-li se na skládku - kvưli jedovatým chemikáliím $v$ bateriích.

- Asi žádný, koupím ho v bazaru bez obalu, baterie mám dobíjecí.

- $\quad$ prírodě, když se pustí moc hlasitě, tak utíkají zvírata.

- Neměla bych nahlas poslouchat $v$ prírodě.

Čtvrté ročníky:

- Zbytečný odpad. Tím, že ho koupím $\rightarrow$ velká poptávka $\rightarrow$ výrobce zvýší produkci.

- Problém odpadu.

- Používal bych alkalické baterie $\rightarrow$ alespoň částečně šetřit ŽP.

- Výroba tohoto výrobku potřebuje továrnu $(-)$, tato továrna zaměstnává lidi $(+)$. Nedá se říci, jestli 1 MP3 má katastrofální dopad na ŽP.

- Na výrobu bude potřeba energie. Nelíbí se mi kácení lesů, protože také zvířata si zaslouží mít svůj domov - jsou součástí planety jako my.

- Baterie do odpadu.

- Velký vliv výrobou - spotřeba surovin.

- Po znehodnocení MP3 přehrávače zůstane $v$ prírodě $z$ části nebezpečný odpad, který se nerozloží.

- Musí se vyrobit další součástky, které, když nejsou ekologicky využity po vyhození př́stroje, mohou škodit ŽP.

- MP3 přehrávač potřebuje baterie $\rightarrow$ jejich likvidace je $v$ některých případech škodlivá k ŽP.

- Musí se do přehrávače kupovat baterie $\rightarrow$ ovlivním ŽP.

- Pokud se rozhodnu něco koupit, nic se tím neovlivní. Ovlivní se to maximálně užíváním zařízení.

- Spotřebou baterií (nebezpečný odpad) bych ovlivnil ŽP.

- Vyhozený přehrávač bude ničit ŽP - není recyklovatelný.

- Koupila bych si takový, u kterého by už měl být poplatek za recyklaci za starý. Pokud bych měla starý a nefunkční, dala bych ho do obchodu, kde jsem koupila nový. 
- Určitě bych dbala na to, co by se dělo po jeho rozbití.

- Při používání MP3 přehrávač nebude nijak ovlivňovat ŽP, jen bude problém s jeho likvidací.

- Rozhoduji se podle kvality a ceny výrobku. Na výrobu je zapotřebí prírodních zdrojů. Na toto neberu ohled, a co se mi líbí a potřebuji, tak to si koupím, at je to vyrobeno $z$ čeho chce. Je mi to jedno!

- Koupí MP3 přehrávače přispěju DPH do státního rozpočtu $\rightarrow$ více peněz na ochranu ŽP.

- Zajímal by mě zdroj energie - např. nabíjecí baterie

- Myslím si, že samotný přehrávač žp neovlivní, ale ovlivní ho baterie, které budou prehrávač napájet - jsou nebezpečným odpadem, který ničí ŽP.

- Ve větší míre ŽP mohou ovlivňovat pouze baterie (prodávají se i nabíjecí $\rightarrow$ malý vliv).

- Takovéto zařízení potřebuje zdroj energie. Pořídil bych nabíjecí baterie. Obyčejné baterie málokdo likviduje ekologicky, spíše skončí na skládce komunálního odpadu.

- Při výběru se soustřed'uji na funkce a vzhled výrobku. ŽP ovlivní koupě především při likvidaci výrobku a spotřebě energie během provozu.

- Ovlivní ho pak následným zpracováním obalu. Ty jsou většinou z plastů a jejich likvidace hodně zatěžuje prostředí.

- Ovlivní ŽP při jeho výrobě. Samotný přehrávač není ŽP nebezpečný.

- Samotnou koupí přehrávače se ŽP neovlivní. To může být ovlivněno výrobou a zacházením s bateriemi tohoto přehrávače.

- Plasty se špatně rozkládají, bude složitá likvidace. To však neovlivní koupi mého MP3 přehrávače.

- Vlastní koupě ne, ale např. výměna baterií. Samotná výroba má také vliv na čistotu okolí.

- Podle mého názoru to není o konkrétní věci. Je ale zřejmé, že každá věc musí být $v$ ochranném obale a to je ten největší problém. Obaly nás jednou zavalí. Měla by se najít nějaká alternativa.

- Spotřeba baterií a jejich likvidace. Na výrobu potřeba prírodních zdrojů.

- Koupě nového MP3 přehrávače vyžaduje koupi nových baterií $\rightarrow$ vyhození starých $\rightarrow$ nový odpad.

- Recyklace plastu je nutná. Jsou potřeba baterie, proto bych volil nabíjecí - více vydrží a nemusí se kupovat nové.

- Koupit přehrávač s nabíjecí baterií $\rightarrow$ nyní odpadová baterie. Nutnost ekologické likvidace. Pokud si to nekoupím já, tak někdo jiný určitě ano. Tak proč si odpírat hezké věci.

- Nad ovlivněním ŽP bych při koupi MP3 přehrávače ani nepřemýšlel, ale vliv na ŽP má spíše jeho výroba a to moje koupení neovlivní.

- Koupě nějakého produktu ŽP neovlivní, ale jeho výroba a potom jeho demolice. 
- Určitě až splní MP3 přehrávač svưj účel nebo bude nefunkční, tak to znamená další odpad. Pro př́rodu přirozenou cestou obtížně odbouratelný. V př́ípadě spálení přehrávače se přispěje ke skleníkovému efektu a narušování ozónové vrstvy.

- $\quad \mathrm{V}$ tom prípadě bych uvažoval $\mathrm{i}$ o dobíjecích bateriích $\mathrm{s}$ dlouhou životností. To zajistí, že můj přehrávač nebude nikomu škodit.

- Koupil bych si nabíjecí baterie.

\section{Verbální porozumění}

Respondenti $v$ této kategorii se snažili odpovědi vyhnout tak, že připustili vliv svého chování na životní prostředí, ale $v$ obecné, vágní rovině. Někteří připouštěli, že pokud by stejné rozhodnutí udělalo více lidí, byl by jeho dopad významnější.

První ročníky:

- Ovlivní to ŽP zásadně, bude-li tento nápad mít více lidí (Pozn.: dva respondenti vypovídali zcela shodně na otevřenou otázku a otázky č. 21 a č. 30 ).

- Hlavní dopad má na ŽP výroba a člověk. Nekoupil bych si ho.

Čtvrté ročníky:

- Konkrétně můj nijak, ale $v$ souvislosti $s$ množstvím ve světě, se to může stát problémem $\rightarrow$ umělé hmoty...

- Jak moc to př́rodu ovlivní ukáže čas, protože nyní je ještě př́liš brzy na odpověd'. Toto zodpoví až naše děti.

- Moje koupě je oproti globálnímu měřítku opravdu nicotná. Tudíž na ekologii planety to nebude mít takový vliv. Lidstvo se samo žene do záhuby, ale řekněte, at́ se vrátí do jeskyně a jedí bobule a umlátí vás klackem.

- Když si ho koupím jenom já, tak nijak. Když nás bude 1000 kupujících, tak asi zásadně.

- Možná ovlivní, ale pouze minimálně.

- Rozhodně ovlivní, ale zanedbatelně.

- Toto rozhodnutí neovlivní ŽP žádným způsobem, a jestli ano, tak mizivě. Kdyby ale toto rozhodnutí udělali všichni na světě, plýtvali bychom ropou a neměli bychom z čeho tvořit benzín a jiné hmoty. To by byl prǔšvih.

\section{Neporozumění}

Tato množina respondentů nepřipouští, že by jejich spotřebitelské chování ovlivňovalo životní prostředí. Někteři převádí odpověd’ na žert, jiní uvádí, že si výrobek stejně koupí, pokud se jim bude líbit.

První ročníky:

- Bude to ovlivňovat můj sluch

- Jeden MP3 přehrávač ŽP neovlivní

- Neovlivním výrobu spotřebního zboží. Když nekoupím já, koupí někdo jiný!! 
- Vůbec mě to neovlivní

- Když si ho koupím jenom já, tak to př́rodu neovlivní.

- Vyrábí se jich hodně, takže jeden stejně nepomůže. I kdybych si ho nekoupil, tak už je stejně na skladě.

- Má to minimální vliv proti ostatním věcem.

- Ž̌P ovlivní jen minimálně. O ŽP se nezajímám.

- Nedokážu si představit, že by někdo házel MP3 do lesa.

- Žádným způsobem neovlivní.

- Nepatrný vliv na ŽP.

- Zanedbatelné ovlivnění ŽP.

- Velice nepatrně ovlivní ŽP.

- Žádným!!!

- Malý vliv na ŽP.

- Žádný.

- Nemá žádný vliv. Pokud si lidé budou pouštět hlasitou hudbu do uší tak jim hrozí, že ohluchnou nebo budou špatně slyšet. Jiný vliv na ŽP na tom nevidím.

- $\quad$ Nijak to ŽP neovlivní.

- Vůbec.

- Myslím si, že MP3 přehrávač má menší vliv než ropná havárie.

- Nevím. Tohle moc neřeším. Koupím si prostě jaký se mi líbí. Jedna MP3 tohle nevyřeší.

- Takové rozhodnutí moc ŽP neovlivní. Je mi to jedno.

- Hudba je hudba.

- Na ŽP asi žádný - nevím, jen to okolí neuslyším.

- Nemá vliv.

- Nevím.

- Nedokážu si představit, že bych nějak ovlivnil ŽP. Leda že bych ho nakonec vyhodil někde $v$ lese nebo do prírody.

- Nemyslím si, že by to nějak poškodilo ŽP.

- Koupím si jaký chci, mne je to jedno.

- Stejně bych ho jednou vyhodil, ale koupil bych si ho.

- Asi ho neovlivní, pokud rozbitý MP3 ekologický zlikviduji.

- Nevím. 
- Asi žádným. Koupím si takový, jaký se mi bude líbit. Pokud ovšem nebudu vyhazovat baterie do př́rody, Žp to nezasáhne.

Čtvrté ročníky:

- Mám už čtyři MP3 přehrávače. Nechápu, jak mưže škodit ŽP.

- $\quad$ ŽP to asi neovlivní.

- Absolutně nijak, je-li MP3 přehrávač vyroben z ekologického materiálu.

- Když vrátím použité baterie do spec. obchodu, tak ŽP neublížím.

- Toto rozhodnutí nebude mít vůbec žádný vliv na ŽP.

- Nemá to žádný vliv. Nijak by mě to neovlivnilo.

- MP3 přehrávač neovlivní ŽP, jen naše zdraví.

- Žádným způsobem.

- Nákupem přehrávače nijak neovlivním ŽP.

- Neovlivní. Mojí poptávkou se jejich výroba nezvýší a je-li už vyroben, tak se také bude muset jako odpad zlikvidovat.

- Moje rozhodnutí neovlivní ŽP. MP3 přehrávač do ovzduší ani nikam jinam nic nevypouští, proto ŽP neovlivní.

- Nijak výrazně to ŽP neovlivní. Alespoň s tím nejsem seznámen.

- Nemá to žádný vliv na ŽP.

- $\quad$ Nebude to mít skoro žádný vliv.

- $\quad$ Nevidím důvod, jak by mohl MP3 přehrávač ovlivnit ŽP.

- V současném pokroku výroby elektroniky by to nemělo nijak výrazně ovlivnit ŽP.

- Nijak zásadně to neovlivní.

- Nejspíš se mi zhorší sluch a nebudu moci naslouchat přírodě. Tím pádem ji nebudu platný.

- $\quad$ Podle mě jedinec nemůže ovlivnit ŽP.

- Nejpravděpodobněji mě toto rozhodnutí ke koupi přehrávače neovlivní. Mohlo by, pokud by to bylo finančně zvýhodněno.

- To, že si MP3 přehrávač koupíme, nezmění vůbec nic, protože když ne já, tak někdo jiný.

- Myslím, že nijak neovlivní ŽP.

- Absolutně nemám tušení. Řekl bych, že to nemá žádný vliv. Bezpředmětný dotaz.

- Koupě MP3 přehrávače nemá vliv. Je to výsměch velkým firmám, které devastují krajinu. Takže pěkně nevhodný dotaz.

- Myslím, že to žádný vliv mít nebude. 
- Jeden MP3 přehrávač nemá takřka žádný vliv na ŽP.

- Myslím, že neovlivní nijak. Jedině, že by byl tak hlasitý a rušil zvěř v okolí.

- Absolutně nijak můj nový MP3 přehrávač nic neovlivní, možná tak mou fantazii.

Bez odpovědi

Tato skupina respondentů bud' neodpověděla vůbec, nebo způsobem, ze kterého nebylo možné poznat, zda si provázanost uvědomují, či nikoliv. Zařazeni sem byli i respondenti, kteří uvedli, že neznají odpověd'. Pro souhrnné zpracování je tato skupina přiřazena mezi studenty, kteří neprojevili porozumění provázanosti mezi svým chováním a životním prostredím.

První ročníky:

- Nepřemýšlím nad tím.

- MP3 přehrávač mám.

- Raději bych investoval do potřebnějších věcí.

- Nějak to neřeším.

- Prodám ho kamarádovi a nechám mu jej na pospas.

- Fakt nevím.

- Nevím.

- Nekoupil bych si ho, protože bych ho neposlouchal.

- Nevím.

Čtvrté ročníky:

- MP3 přehrávač vlastním $\rightarrow$ tuto otázku již řešit nemusím.

- Co to je MP3 přehrávač?

.K ot. č. 8. a 9. - těžko říct, to se uvidí. Ot. č. 11. - podřizuje se zákonům přírody; právo je pouze vymyšlený jev lidmi pro udržení lidské disciplíny!!. K ot.č.14. - nevidím jim do hlavy (Pozn.: irelevantní odpověd' vztahující se k předchozím částem dotazníku).

Vzhledem k malému počtu respondentů nelze výsledky zcela zobecňovat. Ve vztahu $\mathrm{k}$ výchozím hypotézám je možné dojít $\mathrm{k}$ následujícím závěrưm:

H1: Studenti 4. ročníků SPŠS zastávají častěji proenvironmentální postoje než studenti 1 . ročníkü.

Tato hypotéza se nepotvrdila. Rozdíly $v$ postojích měřených pomocí NEP/DSP i rozšiřující škály jsou velmi malé. Studenti prvních ročníků navíc deklarují větší ochotu zapojit se do aktivit souvisejících se životním prostředím. Podrobnější data ke srovnání environmentálních postojů obou skupin jsou obsažena v př́loze.

H2: Menšina studentů SPŠS zastává proenvironmentální postoje.

Tato hypotéza se nepotvrdila. Studenti většinou souhlasí s postoji nového environmentálního paradigmatu, k postojům DSP mají neutrální či lehce souhlasný postoj. Zajímavý je neutrální postoj $k$ tvrzení „problémy a príběhy lidí mimo moje vlastní bydliště jsou vzdálené a v podstatě mě nijak neovlivňuji". 

jednání.

H3: Menšina studentů SPŠS preferuje ve svém životě environmentálně příznivé

Tato hypotéza se potvrdila. Studenti sice vyjadřují souhlas s běžnými formami environmentálně př́znivého jednání (s výjimkou spolupráce s nevládními organizacemi), ve vlastním jednání se ale environmentálně př́íznivě přiliš nechovají. Většina studentů má dobrý vztah $\mathrm{k}$ místu, kde žije a opakovaně navštěvuje přírodu ve svém okolí. Velká většina také třídí doma odpad, většinu také zajímají (dostupné) informace o životním prostředí.

$\mathrm{Na}$ druhé straně, studenti se nechovají environmentálně příznivě $v$ oblasti spotřebitelské a občanské. Přestože větší část tvrdí, že kupuje výrobky s ekoznačkou, pro naprostou většinu není environmentální šetrnost výrobku důvodem ke koupi, pokud je dražší než méně šetrný výrobek. Většina studentů si neuvědomuje souvislosti mezi nakupovaným výrobkem a jeho ekologickou bilancí a nepromítá proto tento aspekt do svého rozhodování. Neochota „platit více" se odráží i ve velmi malé ochotě príspívat na charitativní účely a téměř minimální ochotě přispívat na problémy, související s životním prostředím. V oblasti občanské angažovanosti je zřejmý nezájem studentů jednat $\mathrm{s}$ úřady nebo od nich získávat informace o životním prostředí.

Výsledky průzkumu korespondují se zjištěními Sociologického ústavu i Centra pro výzkum veřejného mínění. Respondenti sice zastávají proenvironmentální postoje, ve svém jednání se jimi ale řídí pouze tehdy, pokud to od nich nevyžaduje větší finanční či časovou investici. To je možné vysvětlit i tak, že deklarované postoje nekorespondují se skutečně zastávanými životními hodnotami, které mohou mít blízko k egocentrismu. Velmi malá je také úroveň uvědomění si odpovědnosti za své jednání a jeho širších, ekologických a sociálních dopadů. Tato souvislost je sice částečně verbálně deklarována, ale nepromítá se do spotřebitelského jednání žáků.

Průzkum také posiluje La Trobovu a Acottovy pochybnosti o validitě NEP/DSP jako relevantního nástroje na měření proenvironmentálních postojů. Je možné, že autory naznačený posun postojů ve společnosti od doby vzniku NEP je již typický i pro studenty českých středních škol, současně že test dostatečně neměří rozdíl mezi deklarovanými a skutečně žitými hodnotami (LaTrobe; Acott, 2000).

\section{Závěr}

Cílem průzkumu bylo přispět $k$ diskusi o míre ekologické gramotnosti žáků prvních a čtvrtých ročníků středních odborných škol. Ekologická gramotnost zde byla chápána jako proenvironmentální postoje, hodnoty, jednání a kritické porozumění respondentů. Průzkum naznačil, že proenvironmentální postoje jsou mezi studenty středních škol poměrně rozšířené. Ukázal ale také poměrně malé rozšíření proenvironmentálního jednání, zejména v oblastech, vyžadujících finanční či časovou investici. Prokázal také, že většina dotazovaných studentů není schopna propojit deklarované postoje se svým běžným spotřebitelským chováním.

Vzhledem k malému vzorku nelze výsledky průzkumu zobecňovat. Do dalších prací by bylo vhodné podrobit kritické diskusi celou metodiku průzkumu, problematické je možná i samotné využití NEP jako klíčového nástroje pro měření ekogramotnosti respondentů. Pokud by výsledky naznačené tímto průzkumem byly dále potvrzeny, bylo by vhodné kriticky zvážit důsledky pro praxi environmentální výchovy ve školní i mimoškolní oblasti. Ta by pravděpodobně měla usilovat o zvnitřnění formálně deklarovaných postojů, změnu spotřebitelského chování žáků, posílení jejich zájmu o občanskou angažovanost i schopnost samostatně vyhodnocovat dopady svého jednání na společnosti i životní prostředí. 


\section{Literatura}

- Capra, F. (1999). Ecoliteracy : The Challenge for Education in the Next Century. Liverpool: Liverpool Schumacher Lectures.

- Cordano, M., Welcomer, S. A., \& Scherer, R. F. (2003). An analysis of the predictive validity of the new ecological paradigm scale. The Journal of Environmental Education, 34(3), 22-28.

- CULEN Gerald R, , \& MONY Preethi R.S, (2003). Assessing environmental literacy in a nonformal youth program. The Journal of Environmental Education,34(4), 26.

- Franěk, M. (2006) Výzkum antropocentrických a biocentrických postojů k prírodě v české populaci. In E. Strejčková (Ed.), Výzkum odcizování člověka prírodè : Závěrečná zpráva [online]. Praha: Toulcův dvůr.

- Kulich, J., \& Dobiášová, M. (2003). Průzkum ekogramotnosti. Bedrník (Př́loha časopisu), 1(2),

- LaLONDE, Roxanne, JACKSON, Edgar L., (2002). The New Environmental Paradigm scale : Has it outlived its usefulness?. Journal of Environmental Education, 32(4), 28-37.

- LaTROBE, Helen $L_{\prime \prime}$, \& Acott, T. G. (2002). A modified NEP/DSP environmental attitudes scale. The Journal of Environmental Education, 32(1), 1-12.

- Morrone, M., Mancl, K., \& Carr, K. (2001). Development of a metric to test group differences in ecological knowledge as one component of environmental literacy. The Journal of Environmental Education. 2001, 32(4), 33-43.

- O' Mahony, M. J, , \& , Fitzgerald, F., (2001). The Performance of the Irish Green-Schools Programme : Results of the Green-Schools Research Projects. : Environmental education unit.

- Rámcový vzdělávací program pro gymnázia. 2006 (2006). Praha: Výzkumný ústav pedagogický v Praze.

- Samanová, G. (2006). Hodnocení ochrany životního prostředí [online] (tisková zpráva 16. 6. 2006). Praha: Sociologický ústav Akademie věd České republiky. Retrieved from http://www.cvvm.cas.cz/upl/zpravy/100594s_oe60616.pdf

- Samanová, G. (2006). Ekologické jednání [online] (Tisková zpráva 14. 6. 2014). Praha: Sociologický ústav Akademie věd České republiky. Retrieved from http://www.cvvm.cas.cz/upl/zpravy/100593s_oe60614.pdf

- Soukup, P. (2001). ISSP : životní prostředí. Praha: Sociologický ústav Akademie věd České republiky.

- Strejčková, E. (2006). Výzkum odcizování člověka př́rodě : Závěrečná zpráva [online]. Praha: Toulcův dvůr.

- $\quad$ Tbilisi Declaration 1977 [online] . .

- Weber, J. H., HAIR Joseph $F_{\prime \prime}$, \& FOWLER Claudia $R_{\prime}$. Developing a measure of perceived environmental risk. The Journal of Environmental Education, 32(1), 28-36. 
Př́lohy

Tabulka 2. Průměrné hodnoty odpovědí na otázky měřící environmentální postoje (Otázky č. 1-20) a posouzení jejich statistické významnosti podle párového T-testu

\begin{tabular}{|c|c|c|c|c|}
\hline $\begin{array}{l}\text { Číslo } \\
\text { otázky }\end{array}$ & $\begin{array}{l}\text { Mean } 1 . \\
\text { ročník }\end{array}$ & $\begin{array}{l}\text { Mean } \\
4 . \\
\text { ročník }\end{array}$ & $P$ & $\begin{array}{l}\text { Významnost } \\
\text { při } a=0.05\end{array}$ \\
\hline 1 & 5.6 & 5.4 & 0.3662 & NE \\
\hline 2 & 5.82 & 5.40 & 0.0492 & ANO \\
\hline 3 & 3.56 & 2.78 & 0.0033 & ANO \\
\hline 4 & 3.15 & 2.88 & 0.2250 & NE \\
\hline 5 & 3.77 & 3.93 & 0.5854 & NE \\
\hline 6 & 5.36 & 5.55 & 0.4093 & NE \\
\hline 7 & 5.77 & 5.89 & 0.5504 & NE \\
\hline 8 & 3.10 & 2.98 & 0.6647 & NE \\
\hline 9 & 3.66 & 3.46 & 0.3950 & NE \\
\hline 10 & 5.33 & 5.34 & 1.0000 & NE \\
\hline 11 & 6.33 & 6.21 & 0.5443 & NE \\
\hline 12 & 5.66 & 6.11 & 0.0595 & NE \\
\hline 13 & 3.97 & 3.62 & 0.2205 & NE \\
\hline 14 & 4.89 & 5.27 & 0.1577 & NE \\
\hline 15 & 4.67 & 4.83 & 0.5521 & NE \\
\hline 16 & 4.37 & 4.30 & 0.8373 & NE \\
\hline 17 & 4.96 & 4.92 & 0.9182 & NE \\
\hline 18 & 4.01 & 3.46 & 0.1010 & NE \\
\hline 19 & 2.71 & 2.08 & 0.0214 & ANO \\
\hline 20 & 4.09 & 3.38 & 0.0256 & ANO \\
\hline
\end{tabular}

Pozn.: Výpočet proveden pomocí QuickCals Online Calculator for Scientists. Dostupné z http://www.graphpad.com/quickcalcs 
Tabulka 3. Posouzení statistické významnosti otázek měřících proenvironmentální jednání (Otázky č. 21-30) podle párového T-testu

\begin{tabular}{|l|l|l||l|l|}
\hline Otázka & $\begin{array}{l}\text { Mean 1. } \\
\text { ročník }\end{array}$ & $\begin{array}{l}\text { Mean } \\
\text { ročník }\end{array}$ & $P$ & $\begin{array}{l}\text { Významnost } \\
\text { při } a=0.05\end{array}$ \\
\hline 21 & 2.82 & 2.84 & 0.8878 & NE \\
\hline 22 & 1.52 & 1.61 & 0.3976 & NE \\
\hline 23 & 1.81 & 1.62 & 0.1955 & NE \\
\hline 24 & 1.04 & 1.00 & 0.7672 & NE \\
\hline 25 & 1.50 & 1.50 & 0.9325 & NE \\
\hline 26 & 1.01 & 0.95 & 0.3332 & NE \\
\hline 27 & 1.65 & 1.47 & 0.4511 & NE \\
\hline 28 & 0.97 & 0.99 & 1.0000 & NE \\
\hline 29 & 2.24 & 2.54 & 0.0283 & ANO \\
\hline 30 & 1.08 & 1.04 & 0.6827 & NE \\
\hline
\end{tabular}

Pozn. č. 1: Výpočet proveden pomocí QuickCals Online Calculator for Scientists. Dostupné z http://www.graphpad.com/quickcalcs

Pozn. č. 2: Testové hodnoty z dotazníku byly převedeny následujícím způsobem: Vícekrát: 3, Jednou: 2, Vůbec: 1, Nevím: 0

Tabulka 4. Četnosti odpovědí na otázku č. 21 - Za posledních šest měsíců jsem navštívil/-a př́rodu ve svém okolí.

\begin{tabular}{|l|l|l|l|l|l|}
\hline $\begin{array}{l}\text { Četnost } \\
\text { výskytu [\%] }\end{array}$ & \multicolumn{2}{l}{ Škála hodnot } \\
\hline Ročník - škola & vícekrát & jednou & vůbec & nevím & bez odpovědi \\
\hline 1. r. Chrudim & 95 & 2,5 & 0 & 2,5 & 0 \\
\hline 1. r. Liberec & 88 & 4 & 4 & 4 & 0 \\
\hline 4. r. Chrudim & 96 & 4 & 0 & 0 & 0 \\
\hline 4. r. Liberec & 87 & 4 & 2 & 7 & 0 \\
\hline
\end{tabular}


Tabulka 5. Četnosti odpovědí na otázku č. 22 - Za posledních šest měsíců jsem navštívil/-a př́rodu v jiné zemi.

\begin{tabular}{|l|l|l|l|l|l|}
\hline $\begin{array}{l}\text { Četnost } \\
\text { výskytu [\%] }\end{array}$ & \multicolumn{4}{l}{ Škála hodnot } \\
\hline Ročník - škola & vícekrát & jednou & vůbec & nevím & bez odpovědi \\
\hline 1. r. Chrudim & 15,5 & 20,5 & 59 & 5 & 0 \\
\hline 1. r. Liberec & 21 & 15 & 60 & 2 & 2 \\
\hline 4. r. Chrudim & 22 & 19,5 & 58,5 & 0 & 0 \\
\hline 4. r. Liberec & 22 & 22 & 50 & 6 & 0 \\
\hline
\end{tabular}

Tabulka 6. Četnosti odpovědí na otázku č. 23 - Za posledních šest měsíců jsem přečetl/-a jakoukoliv publikaci nebo informační zdroj o životním prostředí.

\begin{tabular}{|l|l|l|l|l|l|}
\hline $\begin{array}{l}\text { Četnost } \\
\text { výskytu [\%] }\end{array}$ & \multicolumn{5}{l}{ Škála hodnot } \\
\hline Ročník - škola & vícekrát & jednou & vůbec & nevím & bez odpovědi \\
\hline 1. r. Chrudim & 36 & 23 & 36 & 5 & 0 \\
\hline 1. r. Liberec & 31 & 29 & 25 & 15 & 0 \\
\hline 4. r. Chrudim & 19,5 & 39 & 24 & 17,5 & 0 \\
\hline 4. r. Liberec & 22 & 28 & 37 & 11 & 2 \\
\hline
\end{tabular}

Tabulka 7. Četnosti odpovědí na otázku č. 24 - Za posledních šest měsíců jsem finančně přispěl/-a na ochranu životního prostředí.

\begin{tabular}{|l|l|l|l|l|l|}
\hline $\begin{array}{l}\text { Četnost } \\
\text { výskytu [\%] }\end{array}$ & \multicolumn{4}{|l}{ Škála hodnot } \\
\hline Ročník - škola & vícekrát & jednou & vůbec & nevím & bez odpovědi \\
\hline 1. r. Chrudim & 8 & 10 & 67 & 15 & 0 \\
\hline 1. r. Liberec & 2 & 9,5 & 73 & 13,5 & 2 \\
\hline 4. r. Chrudim & 11 & 4 & 63 & 22 & 0 \\
\hline 4. r. Liberec & 6,5 & 2 & 72 & 19,5 & 0 \\
\hline
\end{tabular}


Tabulka 8. Četnosti odpovědí na otázku č. 25 - Za posledních šest měsíců jsem finančně přispěl/-a na charitativní účely.

\begin{tabular}{|l|l|l|l|l|l|}
\hline $\begin{array}{l}\text { Četnost } \\
\text { výskytu [\%] }\end{array}$ & \multicolumn{4}{l}{ Škála hodnot } \\
\hline Ročník - škola & vícekrát & jednou & vůbec & nevím & bez odpovědi \\
\hline 1. r. Chrudim & 26 & 18 & 51 & 5 & 0 \\
\hline 1. r. Liberec & 9,5 & 23 & 61,5 & 4 & 2 \\
\hline 4. r. Chrudim & 15 & 26 & 52 & 7 & 0 \\
\hline 4. r. Liberec & 19,5 & 24 & 43,5 & 13 & 0 \\
\hline
\end{tabular}

Tabulka 9. Četnosti odpovědí na otázku č. 26 - Za posledních šest měsíců jsem podepsal/-a petici požadující lepší ochranu životního prostředí nebo se jinak písemně vyjádřil pro tento požadavek.

\begin{tabular}{|l|l|l|l|l|l|}
\hline $\begin{array}{l}\text { Četnost } \\
\text { výskytu [\%] }\end{array}$ & \multicolumn{4}{|l}{ Škála hodnot } \\
\hline Ročník - škola & vícekrát & jednou & vůbec & nevím & bez odpovědi \\
\hline 1. r. Chrudim & 0 & 5 & 87 & 8 & 0 \\
\hline 1. r. Liberec & 0 & 7,5 & 84,5 & 4 & 4 \\
\hline 4. r. Chrudim & 2 & 7 & 74 & 15 & 2 \\
\hline 4. r. Liberec & 2 & 0 & 87 & 11 & 0 \\
\hline
\end{tabular}

Tabulka 10. Četnosti odpovědí na otázku č. 27 - Za posledních šest měsíců jsem koupil/-a výrobek s ekoznačkou.

\begin{tabular}{|l|l|l|l|l|l|}
\hline $\begin{array}{l}\text { Četnost } \\
\text { výskytu [\%] }\end{array}$ & \multicolumn{4}{l}{ Škála hodnot } \\
\hline Ročník - škola & vícekrát & jednou & vůbec & nevím & bez odpovědi \\
\hline 1. r. Chrudim & 49 & 8 & 10 & 33 & 0 \\
\hline 1. r. Liberec & 39 & 15 & 13 & 33 & 0 \\
\hline 4. r. Chrudim & 37 & 13 & 22 & 28 & 0 \\
\hline 4. r. Liberec & 35 & 11 & 8,5 & 45,5 & 0 \\
\hline
\end{tabular}


Tabulka 11. Četnosti odpovědí na otázku č. 28 - Za posledních šest měsíců jsem koupil/-a si dražší výrobek kvůli tomu, že byl šetrnější k životnímu prostředí.

\begin{tabular}{|l|l|l|l|l|l|}
\hline $\begin{array}{l}\text { Četnost } \\
\text { výskytu [\%] }\end{array}$ & \multicolumn{4}{l}{ Škála hodnot } \\
\hline Ročník - škola & vícekrát & jednou & vůbec & nevím & bez odpovědi \\
\hline 1. r. Chrudim & 13 & 2,5 & 46 & 38,5 & 0 \\
\hline 1. r. Liberec & 17 & 6 & 34,5 & 38,5 & 4 \\
\hline 4. r. Chrudim & 9 & 15 & 33 & 41 & 2 \\
\hline 4. r. Liberec & 20 & 9 & 30 & 41 & 0 \\
\hline
\end{tabular}

Tabulka 12. Četnosti odpovědí na otázku č. 29 - Za posledních šest měsíců jsem tř́́dil/-a doma odpad.

\begin{tabular}{|l|l|l|l|l|l|}
\hline $\begin{array}{l}\text { Četnost } \\
\text { výskytu [\%] }\end{array}$ & \multicolumn{4}{l}{ Škála hodnot } \\
\hline Ročník - škola & vícekrát & jednou & vůbec & nevím & bez odpovědi \\
\hline 1. r. Chrudim & 66,5 & 13 & 18 & 2,5 & 0 \\
\hline 1. r. Liberec & 46 & 17 & 33 & 2 & 2 \\
\hline 4. r. Chrudim & 78 & 7 & 13 & 2 & 0 \\
\hline 4. r. Liberec & 76 & 0 & 20 & 4 & 0 \\
\hline
\end{tabular}

Tabulka 13. Četnosti odpovědí na otázku č. 30 - Za posledních šest měsíců jsem využil/-a právo na informace pro otázky související s životním prostředím.

\begin{tabular}{|l|l|l|l|l|l|}
\hline $\begin{array}{l}\text { Četnost } \\
\text { výskytu [\%] }\end{array}$ & \multicolumn{4}{|l}{ Škála hodnot } \\
\hline Ročník - škola & vícekrát & jednou & vůbec & nevím & bez odpovědi \\
\hline 1. r. Chrudim & 0 & 8 & 77 & 15 & 0 \\
\hline 1. r. Liberec & 8 & 11 & 71 & 8 & 2 \\
\hline 4. r. Chrudim & 2 & 8,5 & 82,5 & 7 & 0 \\
\hline 4. r. Liberec & 2 & 2 & 91,5 & 4,5 & 0 \\
\hline
\end{tabular}


Časopis Envigogika vydává Centrum pro otázky životního prostředí UK. Vývoj časopisu je podpořen projektem OP VK Mezioborová sít' udržitelného rozvoje.

Více najdete na internetových stránkách projektu mosur.czp.cuni.cz
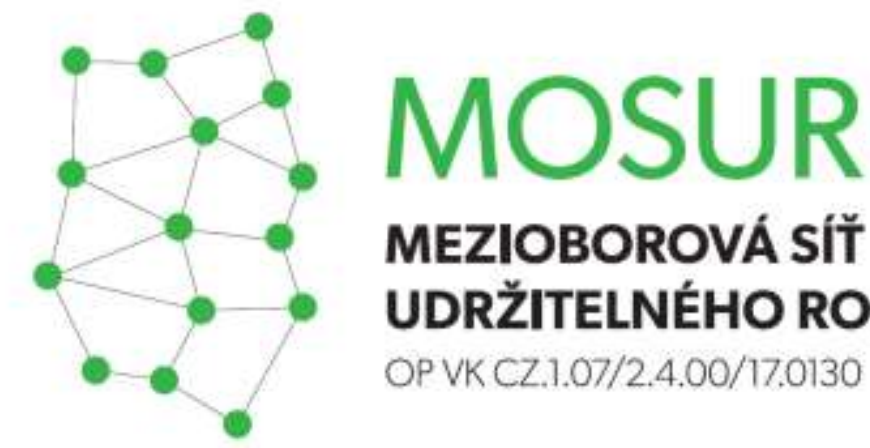

\section{MEZIOBOROVÁ SÍT} UDRŽITELNÉHO ROZVOJE

OPVKCZ.1.07/2.4.00/17.0130

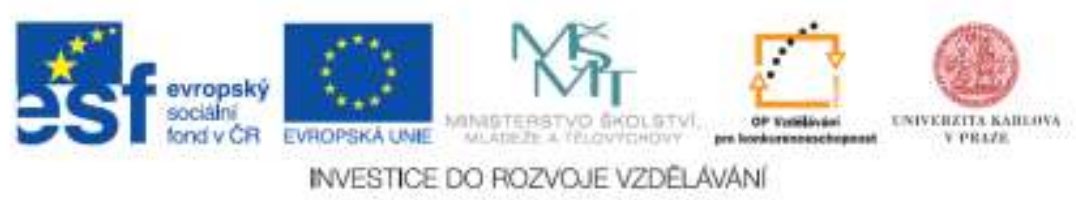

